
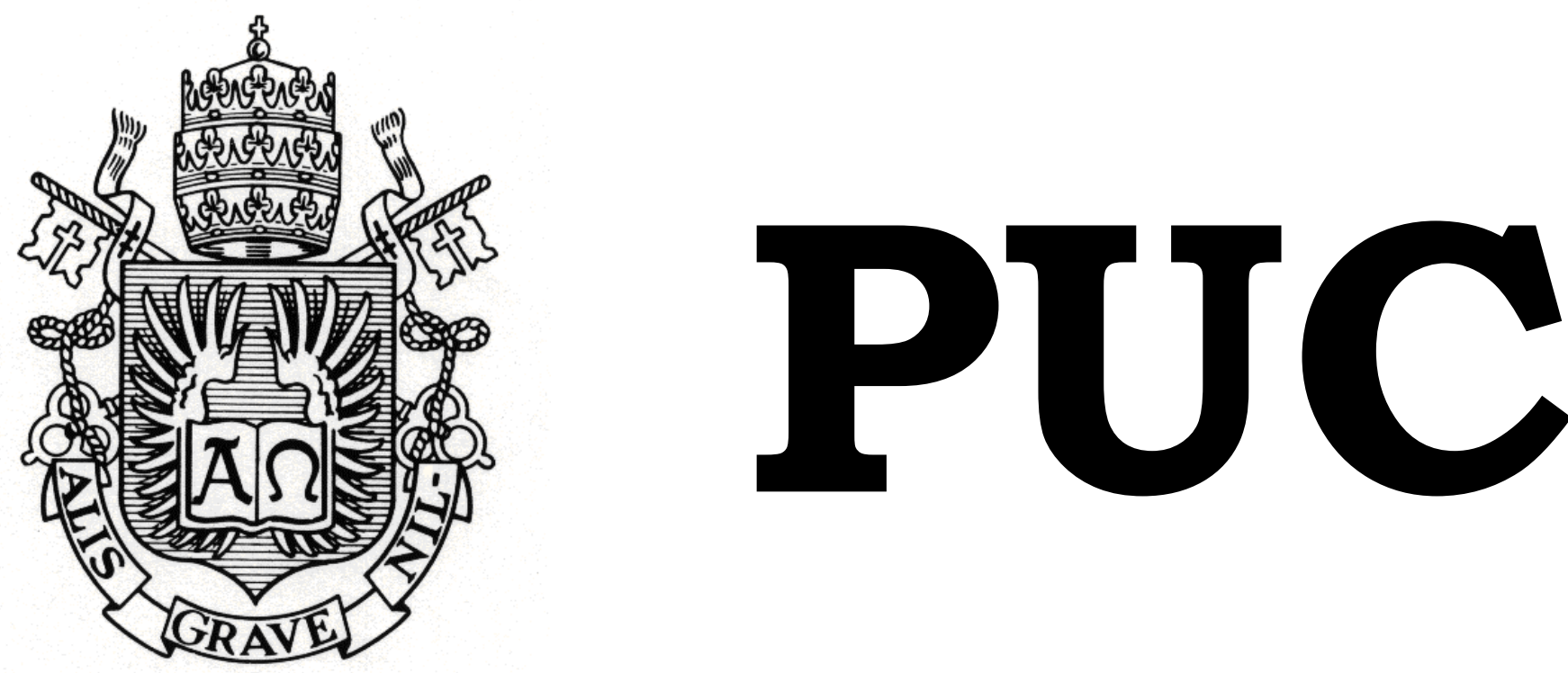

DEPARTAMENTO DE DIREITO

\title{
A FORÇA NORMATIVA DO PRINCÍPIO DA EFICIÊNCIA NA ADMINISTRAÇÃO PÚBLICA
}

por

BERNARDO ROBERTO CARDOSO PINTO

ORIENTADOR: PROF. MANOEL MESSIAS PEIXINHO

2014.2 


\section{A FORÇA NORMATIVA DO PRINCÍPIO DA EFICIÊNCIA NA ADMINISTRAÇÃO PÚBLICA}

por

\section{BERNARDO ROBERTO CARDOSO PINTO}

Monografia apresentada ao Departamento de Direito da Pontificia Universidade Católica do Rio de Janeiro (PUC-Rio) para a obtenção do Título de Bacharel em Direito.

Orientador: Prof. ${ }^{\circ}$ Doutor Manoel Messias Peixinho. 


\section{DEDICATÓRIA}

Dedico o presente estudo às minhas irmãs Larissa e Verônica, aquelas que suportaram por esses anos o maior sacrifício para a minha Graduação: a ausência. Contem sempre com o meu sempiterno amor. 


\section{AGRADECIMENTOS}

De tanto transbordar-me a alma de gratidão seriam insuficientes centenas de laudas para que aqui se fizesse constar todos aqueles ao qual devo uma palavra de agradecimento. Gostaria que todos aqueles com quem convivi nesses últimos cinco anos se sentissem abraçados.

\section{Agradeço a Deus, pois Ele tem precedência sobre tudo;}

Agradeço aos meus pais, Jorge e Genilda, pela infinita dedicação e amor incondicional;

Ao Estado Brasileiro, pela oportunidade;

À Igreja Católica Apostólica Romana, pela formação teológica, ética e moral;

À Pontifícia Universidade Católica do Rio de Janeiro, minha alma mater, pela atividade científica e social desenvolvida;

Ao Presidente Paulo Melo, por viabilizar o meu sonho;

Ao Marco Antônio Cabral, pela amizade e confiança;

Aos tantos amigos pontifícios, família que construí durante os anos da Graduação;

Aos amigos do Curso de Direito da Universidade Gama Filho, pelas discussões jurídicas e o almejo de um mundo mais justo;

Ao Túnel Rebouças, aquele que é via de união numa cidade que nunca deveria ter deixado dividir-se;

Aos Docentes, Funcionários e Colaboradores dessa Instituição que tanto se dedicam para que nós possamos crescer como acadêmicos e Seres Humanos;

Finalmente, ao meu professor-orientador, estimado amigo, Doutor Manoel Messias Peixinho, por compartilhar a sua magnífica erudição, exercer a docência com gáudio e conduzir a vida com extremo bom humor. Serei eternamente grato. 


\section{RESUMO}

A presente monografia pretende investigar a aplicação do Princípio Constitucional da Eficiência na Administração Pública através da defesa da sua normatividade. Percorreremos neste trabalho, de forma sintética, a origem do Poder estatal, sua instrumentalização através do Direito Administrativo, a força normativa constitucional, os princípios que esta impõe à Administração, a possibilidade de controle jurisdicional dos atos administrativos com base no princípio em tela e o entendimento contemporâneo das finalidades do Estado. Árbitro ou provedor?

Palavras-Chave: Direito Administrativo - Direito Constitucional Princípios Constitucionais Administrativos - Normatividade dos Princípios - Princípio da Eficiência - Eficiência, eficácia e efetividade Administração Pública Contemporânea - Serviço Público - Fins do Estado. 


\section{SUMÁRIO}

RESUMO

04

INTRODUÇÃO:

Mudança de paradigma na Administração Pública do Estado Brasileiro: o Princípio da Eficiência como baliza ......................................... 07

\section{CAPÍTULO I:}

A força normativa da Constituição ................................................... 13

1.1 Os Princípios em Ronald Dworkin e Robert Alexy ................... 15

1.2 A força normativa dos Princípios ............................................... 16

\section{CAPÍTULO II:}

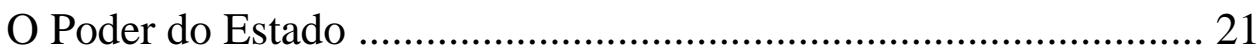

2.2 A unicidade e indivisibilidade do Poder .................................... 23

2.1 A capacidade de auto-organização ............................................. 24

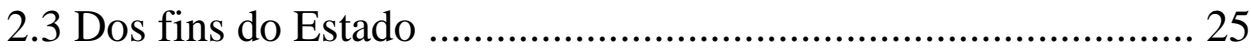

\section{CAPÍTULO III:}

Administração Pública brasileira em mutação 27

\section{CAPÍTULO IV:}

A Administração Pública na Constituição de 1988 ............................ 39

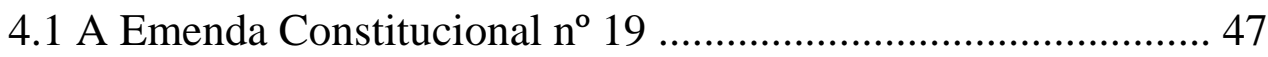

4.2 Princípios da Administração Pública ........................................... 49

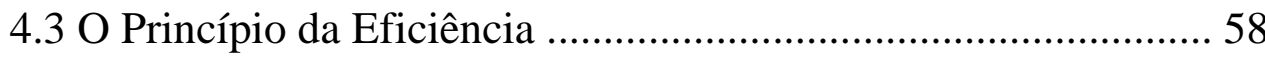




\section{CAPÍtULO V:}

O Princípio da Eficiência como princípio conglobante 61

5.1 Eficiência, eficácia e efetividade 62

5.2 O Princípio da Eficiência como direito fundamental 63

5.3 O controle jurisdicional do ato administrativo com base no Princípio da Eficiência 66

\section{CONCLUSÃO:}

A força normativa do Princípio da Eficiência: a prevalência dos elementos finalísticos sobre os elementos formais 68 


\section{INTRODUÇÃO}

Quis o destino que a elaboração da presente monografia se desse num momento tão singular para a jovem Democracia brasileira. Após acompanharmos manifestações civis que não se dirigiam a um governo ou governante em específico, devemos voltar nossos olhares para o motivo, ou motivos, que deflagraram tais eventos pelo país.

Os referidos atos se configuram como a externalização de um conjunto de insatisfações presentes no sentimento popular, no fato de ser Cidadão Brasileiro. De certo, tão variadas eram as demandas apresentadas legitimamente pelo Povo que a sua soma representa verdadeiro clamor pela reforma do Estado.

Curiosa é a insatisfação-gênese do movimento que tomou as ruas: a precariedade do serviço de transporte público e a ineficiência do Estado em gerir os meios que constituem a chamada mobilidade urbana ${ }^{1}$, o consagrado direito constitucional de ir, vir e permanecer. A indignação gerada pela constatação da ineficaz gestão das regiões metropolitanas se uniu às constatações mais antigas. A ausência da qualidade na maior parte das instituições públicas (e particulares) de ensino; a ausência do bem intangível da segurança pública; a resposta inadequada do Sistema Único de Saúde à escalada em projeção geométrica da demanda; ao crescente desencontro entre as expectativas geradas pela consagração na Carta Magna de 1988 de direitos inéditos e a sua inatingibilidade pelo cidadão-médio brasileiro.

Que seria isso senão a ineficiência do Estado?

${ }^{1}$ PERO, V.; MIHESSEN, V. Mobilidade Urbana e Pobreza no Rio de Janeiro. Rio de Janeiro: BNDES/ANPEC, 2012 (Séries Working Paper BNDES/ANPEC nº 46). 
É nesse cenário que pretendemos, ainda que de forma sucinta, analisar através da Doutrina a força normativa do Princípio da Eficiência ${ }^{23}$ na Administração Pública do Estado brasileiro.

Aqui devemos abrir parênteses para que se faça relevante observação. Apesar do princípio da eficiência ter sido incluído explicitamente no texto da Carta através da Emenda Constitucional 19, de 4.6.1998, ou seja, há mais de quinze anos, pouco se aprofundou nesse importante instituto norteador. Corriqueiramente as obras administrativistas tem reservado a ele diminutas considerações ${ }^{4}$.

A critica recorrente reside na atribuição feita pela Emenda Constitucional 19 à Administração de um princípio dito "aberto", tratandose de facto em "letra morta". Ora, caso se trate verdadeiramente de um princípio "aberto", cabe aos operadores do Direito delimitá-lo, sendo congruentes com a finalidade buscada pelo Constituinte. A nosso ver, não se deve apenas afastar importante paradigma com o raso argumento de que este pode ou não comportar interpretações.

Receio maior reside na força normativa do referido princípio. Em que pese alguns considerarem inviável o controle jurisdicional do ato administrativo sob a tutela do princípio da eficiência ${ }^{6}$, como testemunhas de uma transição do modelo burocrático para o novo modelo gerencial administrativista, faz-se inevitável nos alinharmos com Alexandre Santos de Aragão. Segundo o autor, não satisfaz mais ao cidadão a abstenção do

\footnotetext{
${ }^{2}$ BRASIL. Constituição (1988). Constituição da República Federativa do Brasil. Brasília, DF: Senado, 1988.

${ }^{3}$ BRASIL. Lei n. ${ }^{\circ}$ 9.784, de 29 de Janeiro de 1999. Regula o processo administrativo no âmbito da Administração Pública Federal. Diário Oficial [da] República Federativa do Brasil, Brasília, DF, 11 mar. 1999.

${ }^{4}$ CARVALHO FILHO, José dos Santos. Manual de direito administrativo. $25^{\mathrm{a}}$ ed. Rio de Janeiro: Atlas: 2012, pp. 29-31.

${ }^{5}$ RIGOLIN, Ivan Barbosa. O servidor público nas reformas constitucionais. Rio de Janeiro: Fórum: 2003, p. 26. apud Ibid., p. 29.

${ }^{6}$ FRANÇA, Vladimir da Rocha. Eficiência administrativa na Constituição Federal. Revista de Direito Administrativo, v. 220, 2000, p. 175.
} 
administrador de violar a lei. Nem é o caso de menospreza-la, mas atender de forma valorosa os seus elementos finalísticos ${ }^{7}$.

Pela defesa do controle jurisdicional do ato administrativo com base no Princípio da Eficiência, nos agasalhamos nos ensinamentos de Sérgio Ferraz e Adilson Abreu Dallari, presentes em sua magistral obra ${ }^{8}$.

Feita tal consideração, devemos continuar nossa jornada (quase) solitária na busca da eficiência na administração através da normatividade do princípio em tela. Nesse modesto trabalho, vamos percorrer o roteiro que se apresenta nos próximos parágrafos.

Ainda em nosso primeiro capítulo analisaremos a chamada força normativa ${ }^{9}$ da Constituição, ou seja, a sua imperatividade ${ }^{10}$ no ordenamento jurídico. Sendo a Carta um repositório de regras e princípios, analisaremos a normatividade desses últimos através das consagradas teorias de Ronald Dworkin $^{11}$ e Robert Alexy ${ }^{12}$.

Tratando-se de Direito Administrativo, a ciência que tem como finalidade instrumentalizar através da Administração Pública o Poder uno e soberano do Estado, faz-se imprescindível no caminhar da nossa investigação analisarmos, ainda que de forma sintética, elementos da Teoria Geral do Estado ${ }^{13}$ e da Ciência Política ${ }^{14}$. É no segundo capítulo que analisaremos o Poder e os Fins da entidade Estatal.

\footnotetext{
${ }^{7}$ ARAGÃO, Alexandre Santos. O Princípio da Eficiência. Revista Eletrônica de Direito Administrativo Econômico, Salvador, Instituto de Direito Público da Bahia, no 4, nov/dez 2005, jan 2006. Disponível em <http://www.direitodoestado.com>. Acesso em: 26 de Outubro de 2014.

${ }^{8}$ FERRAZ, Sérgio e DALLARI, Adilson Abreu. Processo administrativo. $3^{\text {a }}$ ed. São Paulo: Malheiros Editores, 2001, p. 123.

${ }^{9}$ HESSE, Konrad. A força normativa da Constituição. Trad. Gilmar Ferreira Mendes. Porto Alegre: Sérgio Fabris Editor, 1991. [orig. Die normative Kraft der Verfassung, J.C.B. Mohr (Paul Siebeck), Tübingen].

${ }^{10}$ BARROSO, Luís Roberto. Curso de direito constitucional contemporâneo: os conceitos fundamentais e a construção do novo modelo. $3^{\mathrm{a}}$ ed. São Paulo: Saraiva, 2011.

${ }^{11}$ DWORKIN, Ronald. Uma questão de princípio. São Paulo: Martins Fontes, 2000.

${ }^{12}$ ALEXY, Robert. Teoria dos direitos fundamentais. Trad. Virgílio A. Da Silva. São Paulo: Malheiros Editores, 2008.

${ }^{13}$ BONAVIDES, Paulo. Teoria do Estado, $8^{a}$ ed., São Paulo: Malheiros Editores, 2010.

${ }^{14}$ BONAVIDES, Paulo. Ciência Política, $18^{\mathrm{a}}$ ed. São Paulo: Malheiros Editores, 2011.
} 
No capítulo subsequente, o terceiro, vamos pontuar as quebras de paradigma ocorridas na Administração Pública pátria, desde o império até os dias atuais. A transição ocorrida entre os modelos de Administração patrimonialista, burocrática e gerencial ${ }^{15}$.

Feitas as considerações sobre o histórico administrativista brasileiro, é no quarto capítulo que nos debruçaremos sobre o texto constitucional vigente para examinarmos a Administração contemporânea. Quais funções e finalidades atribuiu a ela o Constituinte?

$\mathrm{Na}$ tentativa de avaliar o modelo pretendido pela Lei Maior, passaremos a elencar os princípios administrativos (explícitos e implícitos) por ela consagrados originalmente e após a Emenda Constitucional n ${ }^{\circ} 19$.

No derradeiro capítulo, adentraremos ao tema central deste trabalho monográfico. A capacidade do Princípio da Eficiência, pareado com o Princípio da Legalidade, de englobar os fins da Administração. Para nos auxiliar na defesa cientifica dessa proposta lançaremos mão das lições solares de Costa Machado ${ }^{16}$, Manoel Jorge ${ }^{17}$, Gilmar Mendes ${ }^{18}$, José Afonso da Silva ${ }^{19}$, dentre outros.

Nessa mesma subseção faremos a diferenciação entre eficiência, eficácia e efetividade. Componentes semelhantes, mas não idênticos, que se autocompletam. Esses três componentes são partes indispensáveis ao verdadeiro conceito que reside no Princípio da Eficiência.

\footnotetext{
${ }^{15}$ MELLO, Celso Antônio Bandeira de. Curso de Direito Administrativo. $31^{\text {a }}$ ed. São Paulo: Malheiros Editores, 2014, p. 110.

${ }^{16}$ MACHADO, COSTA. Constituição Federal Interpretada, artigo por artigo, parágrafo por parágrafo. $4^{a}$ ed. Barueri: Manole, 2013.

${ }^{17}$ SILVA NETO, Manoel Jorge. Curso de direito constitucional. $5^{\text {a }}$ ed., Rio de Janeiro: Lumen Juris, 2009.

${ }^{18}$ MENDES, Gilmar Ferreira; BRANCO, Paulo Gustavo Gonet. Curso de Direito Constitucional. $6^{\mathrm{a}}$ ed. São Paulo: Saraiva, 2011.

${ }^{19}$ SILVA, José Afonso da. Aplicabilidade das normas constitucionais. $7^{\mathrm{a}}$ ed. São Paulo: Malheiros Editores, 2007.
} 
Carlos Weis ${ }^{20}$ será nosso alicerce na leitura do Princípio da Eficiência como componente dos direitos fundamentais. E, tendo como mote tal leitura, avançaremos no esmiuçamento do controle jurisdicional do ato administrativo com base no Princípio da Eficiência.

Concluídas as considerações sobre a normatividade do princípio aqui tratado, reservamo-nos ao direito-dever de tecer razoáveis linhas sobre $a$ prevalência dos elementos finalísticos sobre os elementos formais da Lei administrativista, uma (re)leitura daquilo que modernamente se propõe o Estado enquanto serviente do cidadão, do seu Povo.

Passamos de uma invasão total do Estado no âmbito privado para, após, uma abstenção absoluta. Experimentamos também um estado que se fez empresário e vivemos um momento onde nem o excesso nem o mínimo se fazem suficientes. Queremos um Estado árbitro ou provedor? Se no âmbito afetivo-cultural podemos nos considerar filhos da Nação, temos que impor a este pai relapso as obrigações a ele imputadas pela nossa Carta Fundante. Obrigações estas negativas, como abster-se de molestar, e obrigações positivas, entendidas como o provimento eficiente daquilo que é justo aos seus Administrados.

Esperamos, se não responder, ao menos formular com mínima sapiência as complexas e profundas indagações que a realidade nos impõe.

\footnotetext{
${ }^{20}$ WEIS, Carlos. Direitos humanos contemporâneos. 2a ed. São Paulo: Malheiros Editores, 2012.
} 
"O Estado é modelado em função das finalidades que lhe são atribuidas.

(...) O Estado organiza-se, pois, para servir, qualquer que seja a sua coloração doutrinária. Enquanto se organiza para atender a fins sociais e econômicos, constitui-se como um sistema de serviços públicos."

Miguel Reale ${ }^{21}$

\footnotetext{
${ }^{21}$ REALE, Miguel. Lições Preliminares de Direito. 27a ed. São Paulo: Saraiva, 2014, p. 344.
} 


\section{CAPÍTULO I - A FORÇA NORMATIVA DA CONSTITUIÇÃO 2223242526}

O Capítulo inaugural do presente trabalho monográfico é mais que propedêutico, é o próprio liame que vai unir as teorias e propostas apresentadas com o intuito de defender a tese desenvolvida. Como o próprio tema nos assinala, a força normativa do princípio da eficiência na Administração Pública congloba a própria Teoria dos Princípios, elementos esses transformados pelo pós-positivismo. Normas constitucionais e a própria Constituição hão de ser brevemente analisados em sua instância científica para que possamos subsidiar os capítulos subsequentes.

A Constituição é o documento inaugural do Estado, sua gênese jurídica. De tal documento emana um feixe normativo que vai alinhar os fatores reais de poder, a atuação do próprio Estado $^{27}$, os demais elementos do ordenamento jurídico e as condutas sociais. Quanto a essa supremacia, dá-se o nome de "força normativa da Constituição"28.

Ao nosso estudo nos é relevante a denominada "vontade da Constituição" (Wille zur Verfassung ${ }^{29}$ ), ou seja, o dever ser constitucional. O ideário constitucional deve sobrepor-se às relações de poder dominantes no Estado, pois, sem a aplicabilidade imediata e eficaz das disposições contidas na Carta abre-se espaço para a sobreposição destas pela práxis, podendo ser esta última o patrimonialismo, o desmando, a impunidade etc.

\footnotetext{
${ }^{22}$ ÁVILA, Humberto. Teoria dos princípios - da definição à aplicação dos princípios jurídicos. $15^{\mathrm{a}}$ ed., revista e ampliada. São Paulo: Malheiros Editores, 2014.

${ }^{23}$ VASCONCELOS, Arnaldo. Teoria da Norma Jurídica. $6^{\mathrm{a}}$ ed. São Paulo: Malheiros Editores, 2006.

${ }^{24}$ FALCÃO, Raimundo Bezerra. Hermenêutica. $2^{\mathrm{a}}$ ed. São Paulo: Malheiros Editores, 2010.

${ }^{25}$ BONAVIDES, Paulo. Curso de direito constitucional. 29a ed. São Paulo: Malheiros Editores, 2014.

${ }^{26}$ BARROSO, Luís Roberto. Curso de direito constitucional contemporâneo: os conceitos fundamentais e a construção do novo modelo. $3^{\text {a }}$ ed. São Paulo: Saraiva, 2011.

${ }^{27}$ SILVA, José Afonso da. Curso de direito constitucional positivo. $34^{\mathrm{a}}$ ed. São Paulo: Malheiros Editores, 2010, p. 46.

${ }^{28}$ HESSE, Konrad. A força normativa da Constituição. Trad. Gilmar Ferreira Mendes. Porto Alegre: Sérgio Fabris Editor, 1991. [orig. Die normative Kraft der Verfassung, J.C.B. Mohr (Paul Siebeck), Tübingen]. p. 3.

${ }^{29}$ Ibid., p. 4.
} 
Argumentando sobre as teorias de Ferdinand Lassalle e Georg Jellinek, Konrad Hesse desenvolve esta importante teoria que busca solucionar o conflito entre a "Constituição jurídica" e a realidade. Desenvolve, para tanto, um sentido de supremacia constitucional, ou seja, a prevalência das normas através de sua eficácia, mesmo quando incompatíveis com a "Constituição real".

Não obstante, houve uma distinção desenvolvida pela doutrina ${ }^{30}$ quanto à delimitação e conceituação da eficácia das normas constitucionais, categorizando-as em: a) normas constitucionais de eficácia plena; b) normas constitucionais de eficácia contida; c) normas constitucionais de eficácia limitada; d) normas programáticas.

Destacamos a abordagem do insigne constitucionalista, Ministro Luís Roberto Barroso:

"Uma das grandes mudanças de paradigma ocorridas ao longo do século $\mathrm{XX}$ foi a atribuição à norma constitucional do status de norma jurídica. Superouse, assim, o modelo adotado na Europa até meados do século passado, no qual a Constituição era vista como um documento essencialmente político, um convite à atuação dos Poderes Públicos. Vigoravam a centralidade da lei e a supremacia do Parlamento, cujos atos eram insuscetíveis de controle judicial. Somente após a Segunda Guerra Mundial é que veio a prevalecer o modelo americano de constitucionalismo, fundado na força normativa da Constituição, documento dotado de supremacia e protegido por mecanismos de controle de constitucionalidade. ${ }^{31 "}$

A doutrina, atenta às particularidades das normas constitucionais, imputou a estas uma classificação dicotômica: regras e princípios. São estas duas, então, espécies de norma. Ambas possuem três núcleos: o mandado (determina-se algo), a permissão (faculta-se algo) e a proibição $(\text { veda-se algo })^{32}$.

\footnotetext{
${ }^{30}$ SILVA, José Afonso da. Aplicabilidade das normas constitucionais. $7^{\mathrm{a}}$ ed. São Paulo: Malheiros Editores, 2007, pp. 81 - 82.

${ }^{31}$ BARROSO, Luís Roberto. Curso de direito constitucional contemporâneo: os conceitos fundamentais e a construção do novo modelo. $3^{\text {a }}$ ed. São Paulo: Saraiva, 2011, pp. 197 - 198.

${ }^{32}$ MENDES, Gilmar Ferreira; BRANCO, Paulo Gustavo Gonet. Curso de Direito Constitucional. $6^{a}$ ed. São Paulo: Saraiva, 2011, pp. $82-83$.
} 


\section{1 - OS PRINCÍPIOS EM RONALD DWORKIN E ROBERT ALEXY}

A distinção entre regras e princípios ganha profundidade a partir dos estudos desenvolvidos por Dworkin e Alexy. Ronald Dworkin encontrou semelhanças entre o princípio normativo e a regra ao passo que ambos estabelecem obrigações jurídicas. A diferenciação se daria, porém, não no maior ou menor grau de vagueza da disposição, mas no tipo de diretiva que apresentam, sendo, portanto, uma distinção qualitativa ${ }^{33}$.

A primeira espécie, a regra, seria aplicada de forma disjuntiva (ou tudo, ou nada ${ }^{34}$ ). A sua antinomia se resolveria pelos métodos clássicos de solução, ou seja, pelo critério hierárquico, de especialidade e cronológico.

Não obstante, os princípios não geram de forma automática as consequências jurídicas previstas no enunciado normativo pela ocorrência da situação fática descrita. Princípios seriam dotados por uma dimensão qualitativa, do peso $^{35}$. Assim sendo, não se resolveria um conflito de princípios pela exclusão, mas pela ponderação entre pesos (importâncias) numa dada situação.

Alexy também adota uma distinção qualitativa para as espécies de normas (regras e princípios). Para o autor, princípios "são normas que ordenam que algo seja realizado na maior medida dentro das possibilidades jurídicas e reais existentes ${ }^{36}$ ". Pareado à Dworkin, Alexy entende ser possível uma gradação na aplicação do princípio, enquanto as regras somente podem ser cumpridas ou não.

$\mathrm{Na}$ convergência entre as duas teorias, distinguem-se regras e princípios através da sua aplicabilidade, caracterizando-se a regra pela sua

\footnotetext{
${ }^{33}$ MENDES, Gilmar Ferreira; BRANCO, Paulo Gustavo Gonet. Curso de Direito Constitucional. $6^{\text {a }}$ ed. São Paulo: Saraiva, 2011. p. 84.

${ }^{34}$ Ibid.

${ }^{35}$ Ibid., p. 85.

${ }^{36}$ ALEXY, Robert. Teoria dos direitos fundamentais. Trad. Virgílio A. Da Silva. São Paulo: Malheiros Editores, 2008, p. 86.
} 
aplicação total ou ausente. Não sendo suficiente o critério da generalidade para a caracterização do princípio ${ }^{37}$.

\section{2 - A NORMATIVIDADE DOS PRINCÍPIOS}

Elevadas as normas constitucionais à categoria de norma jurídica, os princípios passam então por três fases distintas de juridicidade: a) o jusnaturalismo e a fase metafísica e abstrata dos princípios; b) o positivismo jurídico e o ingresso dos princípios nos Código como fonte normativa subsidiária; c) com o pós-positivismo, os princípios passam a ser tratados como direito $^{38}$.

A nós, em particular, é de extrema relevância a terceira fase, o alicerce da tese ora defendida. Sobre o tema, as elucidativas palavras de Bonavides:

"A terceira fase, enfim, é a do pós-positivismo, que corresponde aos grandes momentos constituintes das últimas décadas do século XX. As novas Constituições promulgadas acentuam a hegemonia axiológica dos princípios, convertidos em pedestal normativo sobre o qual assenta todo o edifício jurídico dos novos sistemas constitucionais. ${ }^{39,}$

Em singular maestria, José Afonso da Silva nos introduz a real dimensão dos princípios constitucionais, ao qual disseca etimologicamente:

"A palavra princípio é equívoca. Aparece com sentidos diversos. Apresenta a acepção de começo, de início. Norma de princípio (ou disposição de princípio), por exemplo, significa norma que contém o início ou esquema de um órgão, entidade ou de programa, como são as normas de princípio institutivo e as de princípio programático. Não é nesse sentido que se acha a palavra princípios da expressão princípios fundamentais (...) da Constituição. Princípio aí exprime a noção de "mandamento nuclear de um sistema". A normas são preceitos que tutelam situações subjetivas de vantagem ou de vínculo, ou seja, reconhecem, por um lado, a pessoas ou a entidades a faculdade de realizar certos interesses por ato próprio ou exigindo ação ou abstenção de outrem, e, por outro lado, vinculam pessoas ou entidades à obrigação de submeter-se às exigências de realizar uma prestação, ação ou abstenção em favor de outrem. Os princípios são ordenações que se irradiam e imantam os sistemas de normas, são [como observam Gomes Canotilho e Viltal Moreira] 'núcleos de condensações' nos quais confluem valores e bens constitucionais. Mas, como disseram os mesmos autores, os

${ }^{37}$ MENDES, Gilmar Ferreira; BRANCO, Paulo Gustavo Gonet. Curso de Direito Constitucional. $6^{\text {a }}$ ed. São Paulo: Saraiva, 2011. p. 86.

${ }^{38}$ BONAVIDES, Paulo. Curso de direito constitucional. 29a ed. São Paulo: Malheiros Editores, 2014, pp. $264-268$.

${ }^{39}$ Ibid., p. 269. 
princípios que começam por ser a base das normas jurídicas, podem estar positivamente incorporados, transformando-se em normas-princípio e constituindo preceitos básicos da organização constitucional. ${ }^{40,}$

Contemporaneamente compreendemos a Constituição como um sistema aberto de regras e princípios, submergida em valores jurídicos suprapositivos, no qual o ideal de justiça e realização dos direitos fundamentais desempenha um papel protagonista. Verificamos, assim, que os princípios jurídicos, notadamente os de natureza constitucional, percorreram um processo de ascensão que os levaram da função de fonte subsidiária do Direito (com aplicação nas hipóteses de lacuna legal) para o centro do sistema jurídico.

Quanto ao conteúdo, os princípios constitucionais podem ser categorizados em três grupos: fundamentais; gerais e setoriais ${ }^{41}$. Os princípios constitucionais fundamentais comportam as diretrizes políticas mais importantes, como a opção pelo Estado democrático de direito e a dignidade da pessoa humana. Os princípios constitucionais gerais são pressupostos dessas opções, como a isonomia e a legalidade, por exemplo. Por fim, os princípios constitucionais setoriais, que regem subsistemas inclusos na Constituição, consubstanciando normas como a eficiência na Administração Pública.

Quanto à modalidade de eficácia dos princípios constitucionais, leciona o Ministro Luís Roberto Barroso:

"Toda norma destina-se à produção de algum efeito jurídico. Como consequência, a eficácia jurídica - isto é, a pretensão de atuar sobre a realidade é atributo das normas de Direito. A consumação desses efeitos, a coincidência entre o dever-ser normativo e o ser da realidade, é identificada como efetividade da norma. $\mathrm{O}$ descumprimento de uma norma jurídica, que equivale à não produção dos efeitos a que se destina, é passível de sanção judicial. O Poder Público, de maneira geral e o particular, quando afeta em algum direito seu, podem exigir, judicialmente quando seja o caso, a observância das normas que

\footnotetext{
${ }^{40}$ SILVA, José Afonso da. Curso de direito constitucional positivo. 34 a ed. São Paulo: Malheiros Editores, 2010, pp. $91-92$.

${ }^{41}$ BARROSO, Luís Roberto. Curso de direito constitucional contemporâneo: os conceitos fundamentais e a construção do novo modelo. $3^{\mathrm{a}}$ ed. São Paulo: Saraiva, 2011, p. 318.
} 
tutelam seus interesses. Modernamente, já não é controvertida a tese de que não apenas as regras, mas também os princípios são dotados de eficácia jurídica. ${ }^{42}$,

Quanto à eficácia dos princípios constitucionais na jurisprudência, expôs o acadêmico:

"Há, ainda, uma nova tendência na aplicação do princípio da força normativa, que vem se verificando recentemente na Excelsa Corte, consistente na aplicação imediata de preceitos mais genéricos de nossa Carta Constitucional, como os princípios da impessoalidade, moralidade e da eficiência, previstos no art. 37 da Constituição, sem a necessidade de lei regulamentadora. ${ }^{43}$ " (Grifo nosso).

Verifica-se, portanto, dentre o arcabouço normativo constitucional de regras e princípios, a eficácia plena e imediata desses últimos.

A obra ${ }^{44}$ principiológica do professor Humberto Ávila é de magnífica importância para nós, pois é subsídio para o desenvolvimento da tese aqui abordada. Não apenas por aprofundar-se nos estudos de Robert Alexy e Ronald Dworkin, mas, sobretudo, por confrontá-los e propor uma sistemática muito bem construída da Teoria dos Princípios tendo como base a sua força normativa. Ávila colabora para a construção de uma nova dimensão dos princípios constitucionais.

O professor gaúcho nos desperta para a questão da força normativa dos princípios indagando se estes podem ser definidos como normas “carecedoras de ponderação". Lembra o autor, que para alguns ${ }^{45}$ os princípios possuiriam uma força prima facie, ou seja, irradiam força provisória que pode ser dissipada em razão de princípios contrários. Mesmo admitindo que alguns princípios possuem esta característica, não admite ele ser este um elemento que define os mesmos. Enquanto Robert Alexy e Ronald Dworkin vão distinguir os princípios das regras a partir do seu modo de aplicação e colisão (a primeira espécie por subsunção e a segunda

\footnotetext{
${ }^{42}$ BARROSO, Luís Roberto. Curso de direito constitucional contemporâneo: os conceitos fundamentais e a construção do novo modelo. $3^{a}$ ed. São Paulo: Saraiva, 2011, p. 319.

${ }^{43}$ DANTAS, Eduardo Sousa. A força normativa da constituição e a eficácia das normas constitucionais no direito brasileiro. Revista Direito e Liberdade - ESMARN - v. 11, n. 2, p. 21 $36-\mathrm{jul} / \mathrm{dez} 2009$.

${ }^{44}$ ÁVILA, Humberto. Teoria dos princípios - da definição à aplicação dos princípios jurídicos. $15^{\mathrm{a}}$ ed., revista e ampliada. São Paulo: Malheiros Editores, 2014.

${ }^{45}$ Ibid., p. 149.
} 
por ponderação), levando aos princípios um relativismo axiológico, Ávila afirma ser o modo de aplicação elemento apenas contingente dos princípios. Explica o catedrático:

"É precisamente aqui que entram em cena novas qualificações para a força normativa de determinados princípios. A força normativa de alguns princípios pode ser melhor caracterizada como 'condição estrutural', como bem defendeu Nozick, no sentido de orientar necessariamente a organização e atuação estatal, sem que possa ser afastada diante do caso concreto. ${ }^{46}$ Os princípios do Estado de Direito, da separação dos poderes, republicano e federativo, por exemplo, possuem força normativa, precisamente porque normatizam o modo e o âmbito da atuação estatal, não podendo ser objeto de afastamento diante de princípios colidentes, ainda que possam ser diferentemente conformados. A força normativa de outros princípios pode ser melhor qualificada como eficácia 'pro tanto', no sentido de funcionar como um parâmetro de aplicação normativa que deve ser necessariamente considerado ou servir de contraponto permanente, como sustentou Kagan. ${ }^{47}$ Os princípios da capacidade contributiva e da igualdade, por exemplo, possuem essa força normativa, justamente porque devem servir de critério de aplicação normativa, sem que possam ser objeto de afastamento quando aplicáveis. ${ }^{48,}$

Assim, podemos definir princípios em sua plena normatividade como "normas que atribuem fundamento a outras normas, por indicarem fins a serem promovidos, sem, no entanto, preverem o meio para a sua realização ${ }^{49}$ ". É importante a desvinculação dos princípios, por sua característica de conter a possibilidade de restrição e afastamento da sua incidência, da ausência de vinculação presente nos conselhos e valores. Um conselho pode ser levado em consideração, ou não. Mesmo que aceito, não necessariamente precisa guiar o curso de ação adotado pelo destinatário. Um valor, por sua vez, é algo que estabelece qual comportamento é o mais adequado segundo um determinado sistema de valores, cuja aplicação exige uma operação de prevalência diante de outros valores contrapostos. Tais considerações buscam sinalizar para o fenômeno do "relativismo axiológico", onde há possibilidade de afastamento de todo e qualquer princípios, inclusive aqueles reputados mais fundamentais. O que se busca é

\footnotetext{
${ }^{46}$ NOZICK, Robert. Anarchy, Stae and Utopia, Oxford, Blackwell, 1975, pp. 30 - 32.

${ }^{47}$ KAGAN, Shelly. The Limits of Morality, Oxford, Clarendon, 1989, p. 17.

${ }^{48}$ ÁVILA, Humberto. Teoria dos princípios - da definição à aplicação dos princípios jurídicos. $15^{\mathrm{a}}$ ed., revista e ampliada. São Paulo: Malheiros Editores, 2014, p. 154.

${ }^{49}$ Ibid., p. 155.
} 
evitar o esvaziamento normativo dos princípios, preservando a sua função jurídico-normativa, como observa o Ministro Eros Roberto Grau ${ }^{50}$.

As diversas funções e categorias de princípios vão nos contrapor à sua caracterização meramente pela sua possibilidade de ponderação. Ao contrário, remontando-nos à sua origem como elementos norteadores e estruturantes, podemos afirmar que princípios são também elementos e condições inafastáveis ${ }^{51}$. A construção de uma teoria que busca trazer aos princípios uma posição sedentária na aplicação do Direito se deve ao fato de não serem necessariamente colidentes entre si tais normas. É na sua incidência completa e contínua que reside a realização do próprio fim a que se propõe. Neste ponto, cuja análise do caput do artigo 37 da Constituição se faz inevitável, podemos elencar num mesmo dispositivo alguns princípios setoriais: legalidade, impessoalidade, moralidade, publicidade $\mathrm{e}$ eficiência. Nesse ombreado axiológico, conclui Ávila, em cirúrgica abordagem, pela normatividade total dos princípios, pois:

"O simples fato da aplicação de qualquer norma - seja um princípio, seja uma regra - depender de conexões valorativas entremostradas no ordenamento jurídico e requerer um processo discursivo e argumentativo de avaliação das razões e contrarrazões para determinação do seu conteúdo não quer dizer que o intérprete possa desprezar o modo como a Constituição escolheu normatizar a conduta humana - se por meio da estatuição de uma regra ou de um princípio. Assim, quando estatui regras ou determinados princípios, como aqueles que preveem condições estruturais do exercício do poder ou parâmetros permanentes de aplicação, não cabe ao interprete relativizar esses comandos em nome da ponderação (no sentido estrito de afastabilidade mediante priorização concreta), como se os princípios fossem normas descartáveis e, por isso, desprovidas de normatividade. Cabe-lhe, em vez disso, coerentemente respeitar a normatividade escolhida pela Constituição. Daí a razão da afirmação, feita acima ${ }^{52}$, de que os princípios não são apenas valores cuja realização fica na dependência de meras preferências pessoais, como se o interprete pudesse aplicá-lo apenas quando assim desejasse. Os princípios, ao invés disso, instituem o dever de adotar comportamentos necessários à realização de um determinado estado de coisas. $\mathrm{O}$ essencial é que, mesmo no caso dos princípios, o que for necessário para promover o fim é devido. ${ }^{53}$,

\footnotetext{
${ }^{50}$ GRAU, Eros Roberto. O perigoso artifício da ponderação entre princípios - Sobre a prestação jurisdicional - Direito Penal. São Paulo: Malheiros Editores, 2010, p. 40.

${ }^{51}$ ÁVILA, Humberto. Teoria dos princípios - da definição à aplicação dos princípios jurídicos. $15^{\mathrm{a}}$ ed., revista e ampliada. São Paulo: Malheiros Editores, 2014, p. 158.

${ }^{52}$ Ibid., p. 102.

${ }^{53}$ Ibid., pp. $160-161$.
} 
Embora Ávila estivesse discorrendo acerca dos princípios em geral, é de extrema similitude a sua narrativa com o atual estado de normatividade do princípio da eficiência e aquele ao qual este trabalho propõe. No bojo da "reforma administrativa" foi reformulado o caput do artigo 37 da Carta e inseridos alguns princípios, aqui já elencados. Ocorre que houve um esvaziamento pela práxis da força normativa do princípio da eficiência, muito em decorrência dessa defectibilidade própria dos princípios e pelo afastamento da sua incidência com vistas à "ponderação".

Alinhamo-nos ao autor na defesa de uma maior solidez dos princípios no conjunto normativo, não facultando ao intérprete o afastamento da opção que a Constituição já realizou. Não podemos admitir, por exemplo, a não incidência do principio da eficiência em promoção do princípio da legalidade. Ser legal e ineficaz não atinge ao objetivo do conjunto normativo constitucional. Acertada é a posição defendida de que apenas através da força normativa dos princípios (e por via de consequência o seu não afastamento) é que serão realizadas as perspectivas finalísticas e estruturantes de tais enunciados. $\mathrm{O}$ intérprete não pode reduzir princípio à letra morta utilizando como artifício a aplicação por ponderação.

\section{CAPÍTULO II - O PODER DO ESTADO}

$\mathrm{O}$ objeto do estudo ora pretendido nesse modesto trabalho monográfico nos leva a analise do próprio Estado, destinatário do princípio da eficiência positivado na Constituição. A sua capacidade de autoorganização, a unidade e indivisibilidade do Poder e os fins do Estado são aspectos que devem ser analisados para uma melhor compreensão da necessidade de se ratificar a normatividade do princípio da eficiência sobre a Administração Pública. Um Estado ineficaz não honra o seu (intrínseco) Poder nem atinge as suas finalidades.

O Poder Estatal é elemento constitutivo do Estado, representando o animus societatis, a energia primária que anima um grupo social e cria uma 
comunidade em certo território, dando-lhe características de solidariedade, coesão e união. Afonso Arinos definiu o Poder Estatal como "a faculdade de tomar decisões em nome da coletividade ${ }^{54,}$.

Derivam do Poder a força e a competência, sendo esta última a legitimidade derivada do consentimento. Poder alicerçado apenas em força, sem o elemento legitimador, será sempre um poder de fato, contrapondo-se à sua exteriorização por via legítima e consensual, o poder de direito. Quanto ao exercício imperativo do Poder Estatal, considera Bonavides:

"A minoria dos que impõe à maioria a sua vontade por persuasão, consentimento ou imposição material forma o governo que, tendo a prerrogativa exclusiva do emprego da força, exerce o poder estatal através das leis que obrigam, não porque sejam 'boas, justas ou sábias', mas simplesmente porque são leis, pautas de convivência, imperativos de conduta. Dispõe a autoridade governativa da capacidade unilateral de ditar à massa dos governados, se necessário pela compulsão, o cumprimento irresistível de suas ordens, preceitos e determinações de comportamento social. ${ }^{55,}$

O Estado, portanto, é titular da força coerciva que vai materializar os preceitos constitucionais através da sua imposição, guiando a sociedade pelo traçado legal. Desse poder nascem prerrogativas e atribuições, dentre as quais a da perseguição do bem comum $^{56}$. Miguel Reale leciona que o bem comum é o fundamento último do Direito, assim como o é da soberania, desde que por bem comum se entenda a própria "ordem social justa 57 ". Nas palavras do jurista: “a compreensão da natureza do poder torna-se mais clara quando lembramos que o bem comum não coincide com a ideia particular que cada homem faz do seu próprio bem ${ }^{58}$.

Não obstante, nenhum outro bem merece a melhor definição de bem comum que a ordem jurídica. Este é, de fato, o único bem rigorosamente comum, ou seja, o único bem que todos os participantes da sociedade desejam necessariamente, e que nenhum pode dispensar. Todo aquele que manifestar o seu desejo de viver em sociedade estará vivendo em

\footnotetext{
${ }^{54}$ BONAVIDES, Paulo. Ciência Política, $18^{a}$ ed. São Paulo: Malheiros Editores, 2011, p. 115.

${ }^{55}$ Ibid., p. 117.

${ }^{56}$ REALE, Miguel. Teoria do Direito e do Estado. $5^{\text {a }}$ ed. São Paulo: Saraiva, 2010, p. 107.

${ }^{57}$ Ibid., p. 109.

${ }^{58}$ Ibid.
} 
conformidade com a ordem jurídica. Para a sociedade política, o bem comum ou ordem jurídica é fim. Para os outros grupos sociais, e para cada ser humano vivendo em sociedade, o bem comum ou ordem jurídica é meio de que precisam para atingir seus fins particulares ${ }^{59}$.

O homem é um ser imantado a seus bens, é um ser à procura das coisas que o aperfeiçoam. Há nele uma ânsia natural de progresso. E como a perfeição absoluta é inatingível, vive ele a experimentar formas diferentes de tutela social, conduzido por uma inexaurível esperança de vida melhor. Cada tipo de ordem jurídica e de bem comum depende, em última análise, dos objetivos a que os homens atribuem maior valor. A civilização muda de rumo segundo a qualidade dos fins que ela persegue; chegou a hora de rumarmos para um ideal de Estado que exerça seu poder com vistas a uma atuação socialmente comprometida e mais eficiente.

\section{1 - A UNICIDADE E INDIVISIBILIDADE DO PODER}

O Poder Estatal tem como característica a sua indivisibilidade. Significa dizer que a titularidade desse poder é singular e será sempre do Estado $^{60}$. Tal princípio é resultado de um processo histórico que modificou a titularidade do poder do Estado, antes repartido entre o príncipe e as corporações.

O Estado moderno é dotado de um poder uno e indivisível, que rompe com a ideia de titularidade do Poder Estatal exercida pelo governante. Dessa forma o poder é de titularidade não de um soberano ou uma instituição, mas da própria comunidade. A manifestação do poder, porém, se dá por meio dos órgãos de Estado. No Estado democrático de Direito o poder é de titularidade do Povo e o seu exercício se dá pelos referidos órgãos de Estado, como o Parlamento, o chefe de Estado, o Ministério etc.

\footnotetext{
${ }^{59}$ BONAVIDES, Paulo. Reflexões - Política e Direito. $3^{\text {a }}$ ed. São Paulo: Malheiros Editores, 1998, p. 53.

${ }^{60}$ BONAVIDES, Paulo. Ciência Política, $18^{\mathrm{a}}$ ed. São Paulo: Malheiros Editores, 2011, p. 118.
} 
A unidade e indivisibilidade do Poder Estatal não são incompatíveis com o chamado "princípio da separação de poderes ${ }^{61 "}$, como alertaria o senso comum. Justifica o jurista paraibano:

"O poder do Estado na pessoa do seu titular é indivisível: a divisão só se faz quanto ao exercício do poder, quanto às formas básicas de atividade estatal. Distribuem-se através de três tipos fundamentais para efeito desse mesmo exercício as múltiplas funções do Estado uno: a função legislativa, a função judiciária e a função executiva, que são cometidas a órgãos ou pessoas distintas, com o propósito de evitar a concentração de seu exercício numa única pessoa. (...) Houve tão somente divisão do objeto, das tarefas, dos trabalhos e assuntos pertinentes à ação do Estado, em suma, na boa linguagem jurídica, divisão de competência e não do poder do Estado propriamente dito. ${ }^{62,}$

Compreendemos, desta forma, que apesar da unicidade do Poder Estatal este se materializa e se faz concreto pelo seu exercício, havendo a repartição de funções ou atribuições. Isso corrobora a irradiação do princípio da eficiência para todo o Estado, não apenas para o Poder Executivo. Vincular a Administração Pública significa dizer vincular a todo o Poder Estatal, independentemente da forma na qual esse se manifeste.

\section{2 - A CAPACIDADE DE AUTO-ORGANIZAÇÃO}

Auto-organizar-se é característica determinante do Estado. A faculdade autodeterminativa possui relação com a autonomia constitucional e o poder que essa organização exerce sobre seus componentes. Havendo naquela comunidade instrumentalização do poder dotado de autonomia que atue sobre as perspectivas financeira, policial, militar com capacidade de organização e regulação, ali haverá Estado ${ }^{63}$.

A compreensão de auto-organização estatal é importante para compreendermos mais à frente quais as atribuições (e o porquê delas) do Estado como operador de diversas atividades coletivas, como o transporte público, por exemplo. A referida autonomia Estatal na composição e gerência de tais atividades foi opção constitucional, escolha que promove

\footnotetext{
${ }^{61}$ Para mais detalhes vale a consulta ao pilar democrático do Século XVIII: MONTESQUIEU. Do Espírito das Leis, Tradução: Jean Melville. São Paulo: Martin Claret, 2005.

${ }^{62}$ BONAVIDES, Paulo. Ciência Política, $18^{a}$ ed. São Paulo: Malheiros Editores, 2011, p. 119.

${ }^{63}$ JELLINEK, Georg. Allgemeine Staatslehre. Nabu Press: 2010, p. 427 apud BONAVIDES, Paulo. Ciência Política, $18^{\mathrm{a}}$ ed. São Paulo: Malheiros Editores, 2011, p. 118.
} 
diversos desdobramentos no cotidiano do corpo social. O provimento dos serviços públicos e o poder de polícia ao Estado atribuídos decorrem dessa gênese autogovernativa e suas balizas são as prescrições constitucionais.

Auto-organizar-se possui dois desdobramentos: o externo, que deriva do princípio da soberania; e o interno, que vai submeter todos aqueles que vivem sob a tutela Estatal ao modo como esse se compõe, se ordena e promove o controle das ações de governo por meio da tutela constitucional.

\section{3 - DOS FINS DO ESTADO}

Há uma estreita relação entre os fins do Estado e as funções que ele desempenha. Georg Jellinek buscou categorizá-lo em duas esferas: a objetiva e a subjetiva. Os fins objetivos se dariam sobre o papel representado pelo Estado no desenvolvimento da História da humanidade. Havendo duas ordens de resposta para tal problema: fins universais objetivos - fins comuns a todos os Estados de todos os tempos - e fins particulares objetivos - cada Estado tem seus fins particulares, que resultam das circunstancias em que eles surgiram e se desenvolveram e que são condicionais de sua história. Quanto aos fins subjetivos, é o encontro da relação entre os Estados e os fins individuais. O Estado é sempre uma unidade de fim, ou seja, é uma unidade conseguida pelo desejo de realização de inúmeros fins particulares, sendo importante localizar os fins que conduzem à unificação ${ }^{64}$.

Hobbes e Rousseau, por sua vez, desenvolveram uma categorização contratualista dos fins do Estado, sedimentada no pressuposto de que cada indivíduo é titular de direitos naturais, com base nos quais nasceram a sociedade e o Estado. Haveria fins relativos, numa ideia de solidariedade, razão pela qual the foi dado o nome de "teoria solidarista", e os fins exclusivos e fins concorrentes. Os primeiros dizem respeito exclusivamente ao Estado, como a segurança externa e interna. Por sua vez, os fins

\footnotetext{
${ }^{64}$ BONAVIDES, Paulo. Ciência Política, $18^{\mathrm{a}}$ ed. São Paulo: Malheiros Editores, 2011, p. 111.
} 
concorrentes, de grande importância social, são compostos por elementos essencialmente produtores de cultura geral de um povo e residem, de modo fundamental, nos indivíduos e na sociedade, não no Estado ${ }^{65}$.

O Estado como sociedade política, tem um fim geral, constituindo-se em meio para que os indivíduos e as demais sociedades possam atingir seus respectivos fins particulares. Conclui-se que o fim do Estado é o bem comum, ou seja, o conjunto de todas as condições de vida social que consistam e favoreçam o desenvolvimento integral da personalidade humana. Existe uma característica fundamental que qualifica a finalidade do Estado: este busca o bem comum de um certo povo, situado em determinado território ${ }^{66}$.

Quanto à conexão entre os fins do estado e dos indivíduos sociais que o compõe, faz-se mister as considerações de Reale, in verbis:

"Os serviços públicos são, por conseguinte, os meios e processos através dos quais a autoridade estatal procura satisfazer às aspirações comuns da convivência. (...) Um jurista italiano, Alfredo Rocco, fazendo um confronto entre a atividade puramente jurídica do Estado e a de cunho administrativo, observa que, quando o Estado age na qualidade de administrador, ele visa à satisfação de um interesse próprio, embora os beneficiários reais sejam os indivíduos que o compõem. (...) Levando em conta, porém, além da pertinência do interesse, também a sua imediaticidade e prevalência, podemos dizer que o Direito Administrativo tem por objetivo o sistema de princípios e regras, relativos à realização de serviços públicos, destinados à satisfação de um interesse que, de maneira direta e prevalecente, é do próprio Estado, em razão,

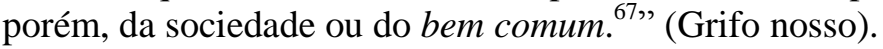

Verifica-se, portanto, que dentre os diversos fins do ente estatal se encontra o provimento e manutenção de bens e serviços indispensáveis à (melhor) realização do indivíduo como componente social do Estado, sendo este provimento e manutenção subordinados às regras e princípios da ordem constitucional-normativa vigente.

O Estado, como se verifica, não é ente que busca a sua autosatisfação como fim, ao contrário, é meio pelo qual se realizam os fins

\footnotetext{
${ }^{65}$ BONAVIDES, Paulo. Ciência Política, $18^{a}$ ed. São Paulo: Malheiros Editores, 2011, p. 147.

${ }^{66}$ REALE, Miguel. Teoria do Direito e do Estado. 5a ed. São Paulo: Saraiva, 2010, p. 115.

${ }^{67}$ REALE, Miguel. Lições Preliminares de Direito. $27^{\text {a }}$.ed São Paulo: Saraiva, 2014, pp. 344 - 345.
} 
individuais, dentre os quais também aqueles que só podem ser exercidos com exclusividade do Estado, pois, os fins exclusivos como a segurança interna e externa também são fatores indispensáveis à paz do corpo social, sentimento intangível sem o qual nenhuma comunidade prospera.

Instrumentalizar tais meios de realização dos fins individuais com eficiência é uma atribuição da Constituição ao Estado brasileiro, sendo toda a atividade da Administração Pública permeada por essa força normativa da norma-princípio.

\section{CAPÍTULO III - ADMINISTRAÇÃO PÚBLICA BRASILEIRA EM MUTAÇÃO 6869707172}

Nas linhas inaugurais do Capítulo que se apresenta, onde percorreremos de forma didática as fases do Direito Administrativo em diversos ordenamentos jurídicos alienígenas que influenciaram o seu desenvolvimento no Brasil, é oportuno transcrevermos uma definição sintética, porém exata, do ramo publicista:

"Partindo para um conceito descritivo, que abrange a Administração Pública em sentido objetivo e subjetivo, definimos o Direito Administrativo como o ramo do direito público que tem por objeto os órgãos, agentes e pessoas jurídicas administrativas que integram a Administração Pública, a atividade jurídica não contenciosa que exerce e os bens que se utiliza para a consecução de seus fins, de natureza pública. ${ }^{73,}$

A origem do Direito Administrativo como ramo do Direito dotado de autonomia remonta ao Século XIX. Apesar de existirem normas administrativas anteriores a esse período, elas se encontravam no seio do jus civile.

\footnotetext{
${ }^{68}$ DI PIETRO, Maria Sylvia Zanella. Direito Administrativo. $27^{\mathrm{a}}$ ed. São Paulo: Atlas, 2014, p. 1 40.

${ }^{69}$ ROCHA, Silvio Luís Ferreira da. Manual de Direito Administrativo. São Paulo: Malheiros Editores, 2013, pp. 41 - 46.

${ }^{70}$ TANAKA, Sônia Yuriko Kanashiro. Direito Administrativo. São Paulo: Malheiros Editores, 2008 , pp. 83 - 87.

${ }^{71}$ MEIRELLES, Hely Lopes. Direito Administrativo brasileiro. $40^{\mathrm{a}}$ ed. atual. São Paulo: Malheiros Editores, 2014, pp. 52 - 53.

${ }^{72}$ CARVALHO FILHO, José dos Santos. Manual de Direito Administrativo. $25^{\text {a }}$ edição. São Paulo: Atlas, 2012, p. 7 - 11

${ }^{73}$ DI PIETRO, Maria Sylvia Zanella. Direito Administrativo. 27a ed. São Paulo: Atlas, 2014, p. 48.
} 
$\mathrm{Na}$ era das monarquias absolutistas o Direito Administrativo não esteve num ambiente sociopolítico propício à formação de sua autonomia. O poder era domínio do soberano e a sua vontade era lei. Nesse período o direito público se esgotava num único preceito: o direito ilimitado de administrar, estruturado sobre as máximas "quod regi placuit lex est; the king can do no wrong; le roi ne peut mal faire". Com a natureza divina dos atos do soberano, sobre estes não podia atuar a jurisdição.

Foi na fase de desenvolvimento do Estado Moderno que o Direito Administrativo (ao lado de outros ramos do direito público, como o Constitucional) teve seu inicial e mais fecundo desenvolvimento. Nessa nova concepção de Estado este toma como bases os princípios da legalidade e da separação ${ }^{74}$ de poderes. Surge o Estado de Direito, onde todos estão submissos à lei, inclusive o monarca.

Pode-se afirmar que o Direito Administrativo é fruto das revoluções, resultado de uma ruptura da ordem política e social absolutista que vinha desde a idade média. Juristas hão de afirmar que o ramo publicista é resultado exclusivamente da Revolução Francesa ${ }^{75}$, só existindo nos países que adotaram os princípios por ela defendidos. Tese que divergimos, data vênia. Historicamente, porém, podemos afirmar que houve um desponte evolutivo do Direito Administrativo na Europa continental pósrevolucionária. A burguesia utilizou-se dos mecanismos publicistas para ora defender-se da classe derrubada, ora para defender-se da classe popular aliada na Revolução e posteriormente reprimida.

O Direito Administrativo, como o próprio conjunto dos fenômenos jurídicos, possui estreita relação com os fatores históricos. Por isso, não se

\footnotetext{
${ }^{74}$ Mais informações sobre a unidade do poder estatal e a separação de suas funções podem ser obtidas na página $\mathrm{n}^{\circ} 23$ da presente monografia.

${ }^{75}$ Acerca desse grande fenômeno histórico, vide: PEIXINHO, Manoel Messias. As contribuições da Revolução Francesa para a construção de uma Teoria Dos Direitos Fundamentais. 2010. 24 p. Disponível em: <http://www.publicadireito.com.br/artigos/?cod=39dd987a9d27f104>. Acesso em: 26 out. 2014.
} 
prospera verdadeira a firmação de que só há sua existência nos sistemas europeus formados com base nos princípios revolucionários. Nem todos os Estados tiveram a mesmo desenvolvimento político e assim não estruturam de forma idêntica o seu poder. Assim sendo, o ramo publicista se desenvolveu de forma heterogênea nos Estados, tendo participação menor do conjunto jurídico em alguns sistemas, como o anglo-americano.

O Direito Administrativo vai variar também de acordo com o tipo de Estado adotado. No denominado Estado de Polícia, onde os fins são a ordem pública, o objeto do Direito Administrativo é bem mais reduzido, devido à quase ausência de intervenção na vida privada.

O Estado do Bem-estar é, por sua, vez protagonista. Não se limita ao estabelecimento da ordem pública, mas atua no provimento de diversas outras atividades, como saúde, educação, assistência social, cultura etc. em decorrência disso, a ampliação do conteúdo do Direito Administrativo. O próprio conceito de serviço público é ampliado, pois atividades antes reservadas à iniciativa privada são submetidas ao regime publicista. A substituição do Estado Liberal, calcado na liberdade de iniciativa, pelo Estado-Providência aumentou de forma significativa o atuar estatal no domínio econômico, lançando mão de novos instrumentos de ação do poder público na fiscalização e disciplina da iniciativa privada. Dessa postura estatal deriva o chamado Direito Econômico.

O Direito Administrativo deve muito do seu desenvolvimento a três escolas publicistas: a francesa, a alemã e a italiana.

É patente a contribuição do direito francês para a autonomia do Direito Administrativo. Indica-se como gênese do Direito Administrativo francês lei datada de 1800, tendo a grande elaboração jurisprudencial do Conselho de Estado francês como fator preponderante para a sua existência.

Como terra natal do princípio da separação dos poderes e a desconfiança histórica nos juízes do Estado, tais fatores fizeram surgir 
naquela realidade a jurisdição administrativa, ou seja, o contencioso administrativo, ao lado da jurisdição comum, criando dessa forma o sistema de dualidade de jurisdição. A partir de 1872 o Conselho de Estado passa a exercer função jurisdicional e foi por meio do funcionamento do referido conselho que se desenvolveram diversos princípios informativos do Direito Administrativo, princípios esses que influenciaram diversos outros países.

Num caso de responsabilidade civil do Estado, conhecido como caso Blanco, um conselheiro do Tribunal de Conflitos francês afastou a incidência do Código de Napoleão e equacionou o conflito em termos publicísticos. O caso é notório pela inédita saída do instituto da responsabilidade do campo do direito civil para o campo do Direito Administrativo.

São quatro os princípios fundamentais do Direito Administrativo francês: a separação das autoridades administrativa e judiciária; a possibilidade de edição de decisões executórias pela Administração; a legalidade (força máxima da lei sobre a Administração); e a responsabilidade do poder público. Naquele sistema jurídico busca-se solucionar com normas e princípios do Direito Administrativo todas as questões em que a Administração é parte, tendo as normas de direito privado incidência subsidiária ao critério do juiz administrativo.

O Direito Administrativo germânico, por sua vez, não surgiu de ruptura uniforme com a ordem jurídica anterior. Ao seu turno, foi produto de longa evolução que não se processou isonomicamente nos Estados alemães.

Foi naquela realidade que se elaborou a teoria do fisco, personalidade jurídica proprietária do patrimônio público sob a tutela do direito privado. Daí decorre o fato de que naquelas circunstâncias eram submetidas questões onde a Administração era parte à regência do Direito 
Civil. Não há aqui, como havia na realidade francesa, dualidade de jurisdição.

No Estado Moderno alemão desapareceu a dicotomia entre o Estado e o Fisco, porém, manteve-se a ideia de submissão de uma parte da atividade estatal ao Direito Civil. Na evolução história, diante da nova realidade daquele Estado, houve evolução do Direito Administrativo, utilizado de forma protagonista na regência das relações entre o ente e seus administrados. O direito privado passou, então, a ter incidência subsidiária. O processo de mudança foi lento, sem revoluções, e resultou da práxis e do trabalho silente da doutrina. Esta, por sua vez, teve papel preponderante no desenvolvimento do ramo publicista naquele país.

$\mathrm{Na}$ formação do Direito Administrativo germânico houve uma influência muito maior do direito privado do que ocorreu no direito francês. Enquanto na formação do Direito Administrativo francês a tendência foi de rejeição das normas de direito privado, na formação alemã se verificou uma tendência em adaptá-las. Naquele país a expressão direito administrativo não se refere a um ramo autônomo do Direito, tal expressão designa todas as normas que regulam a atividade das autoridades estatais administrativas, quer façam parte do direito público ou do direito privado.

Num primeiro momento, o desenvolvimento Direito Administrativo ítalo se deu num ambiente onde não houve rompimento brusco com o regime antecessor. Sua origem se deu sob domínio francês, tendo origem no ordenamento administrativo piemontês. Devido a essas circunstâncias geopolíticas, o ramo publicista naquele país teve grande influência do direito francês desenvolvido a partir da era napoleônica.

Em uma segunda fase, que ocorreu entre 1865 e a Primeira Guerra Mundial, houve reflexo nas legislações dos princípios liberais dominantes na Europa do século XIX. Entre 1922 e 1943, com a ascensão do fascismo, houve a eliminação dos pressupostos democráticos do ordenamento jurídico 
e um regime marcado pelo autoritarismo. A partir da extinção do domínio fascista, se verifica o retorno dos princípios democráticos, a criação de órgãos colegiados com cargos eletivos e limitação do exercício do poder estatal.

Apropriando-se da produção doutrinária de ordenamentos alienígenas, como o francês e o alemão, harmonizou o Direito Administrativo italiano as duas tendências estrangeiras: a primeira, que se apegou ao caso concreto e a jurisprudência e a segunda, que teve um desenvolvimento abstrativista, distante da realidade.

Como é sabido, o direito vigente na Inglaterra e nos Estados Unidos da América integram o sistema da common law, onde as principais fontes são os costumes e a jurisprudência. Enquanto no sistema romanista a fonte mor é o direito legislado, naquele sistema os precedentes e a equidade possuem papel protagonista na fundamentação das decisões judiciais. Há, de certo, a legislação escrita, e onde há conflito entre a construção consuetudinária e a lei, esta última prevalece.

O desenvolvimento do Direito Administrativo anglo-saxão é posterior ao da Europa continental. Ao contrário do que ocorre nos sistemas romanísticos, aqui o Poder Judiciário exerce tanto sobre os particulares quanto sobre a Administração o mesmo controle. O que se buscou no desenvolvimento publicista ango-saxão foi a limitação do Poder Executivo e a sua equalização ao particular.

Na evolução histórica da organização administrativa inglesa nota-se, em particular na primeira metade do século XIX, uma ausência burocrática, como a não previsão legal do exercício de diversos cargos públicos (como secretários de estado, por exemplo), embora tais funções fossem exercidas de fato. O poder era descentralizado, se desenvolvendo por governança local e o poder central se materializava na figura do Parlamento. Houve 
ainda, entre os séculos XVI e XIX um acúmulo de funções administrativas e judiciais, onde os juízes praticavam as duas espécies de atos.

Por seu traçado histórico, a Administração na Inglaterra goza de ampla discricionariedade, podendo o Parlamento, inclusive, delegar a ela o poder de mudar a lei. Foi longa a demora daquele sistema em adotar a teoria de responsabilidade civil do Estado, pois, até 1947, imperava a máxima absolutista "the king can do no wrong". Nesse período o funcionário público era quem respondia pelos danos causados ao particular. Há no sistema jurídico em tela inequívoco predomínio do direito privado na regência das relações administrativas.

Nos Estados Unidos da América verifica-se uma limitação do conteúdo do Direito Administrativo, isso se dá porque toda a matéria relativa à organização administrativa se tutela exclusivamente pela Ciência da Administração, ramo da Ciência Política. As relações entre a Administração e os seus funcionários são regidas pelo direito comum, sendo apenas objeto do Direito Administrativo as relações entre a Administração e os particulares.

Podemos destacar aqui as peculiaridades do sistema administrativo norte americano, destacadamente: ausência de jurisdição administrativa (contencioso administrativo); controle judicial de qualquer ato administrativo; doutrina de irresponsabilidade do Estado; a execução forçada dos atos administrativos é limitada, podendo ser carecedora de autorização judicial; não há regime de emprego público; não há jurisprudência administrativa consolidada, sendo escasso o desenvolvimento da doutrina na área.

Portanto, comparando os dois sistemas (o europeu continental, de inspiração romana e o do commom law) se verifica neste último a predominância do regime jurídico de direito privado nas relações da Administração com os seus funcionários e os particulares. 
Ao cabo da análise dos sistemas que vieram a influenciar o Direito Administrativo pátrio, vamos agora nos debruçar sobre quais foram essas influências, a sua origem histórica e o seu desenvolvimento e, por fim, as suas tendências mais atuais.

Enquanto do período monárquico, não gozava o Direito Administrativo no Brasil de autonomia. Na fase colonial, os donatários das capitanias detinham poderes absolutos que lhes foram outorgados pelo monarca, concentrando-se e se confundido as atividades de administração, legislação e distribuição de justiça. Com a criação do governo-geral houve relativa divisão das atividades entre o governador-geral, o provedor-mor e o ouvidor-geral, mas ainda com forte concentração de poderes ao primeiro. É no Império que ocorre a separação de funções entres os Poderes legislativo, judiciário, executivo e moderador. Nessa realidade já se verificava uma administração pública organizada, mas regida pelo direito privado.

A partir de 1857 se inicia a produção doutrinária na seara administrativista, com a vanguarda de Vicente Pereira Rego e sua obra Elementos de direito administrativo brasileiro, daquele ano.

O advento da República teve como consequência a supressão do Poder Moderador. Inicia-se um processo de dinamismo administrativo e afastamento do direito privado. No início do período republicano, curiosamente, se constatou uma forte influencia norte-americana através da common law, não criando um ambiente próspero ao desenvolvimento do Direito Administrativo.

É em 1934 que o ramo publicista vai encontrar abrigo no seio constitucional, tendo a sua previsão na Carta e o ingresso da atuação do Estado em campos como o social e o econômico. Houve, por essa oportunidade, a instituição do primeiro órgão com jurisdição administrativa, o Tribunal de Direito Administrativo, na esfera federal. A Constituição de 1934 é de mote revolucionário e criou uma ruptura com a ordem da Carta 
de 1891 que era de cunho individualista e previa um Estado liberal, apenas guardião da ordem pública. As consequências da nova ordem jurídica é o crescimento da máquina estatal e, por via de consequência, o enriquecimento do Direito Administrativo pátrio.

Ocorreu, inequivocamente, o influenciamento do Direito Administrativo por ordenamentos jurídicos estrangeiros, notadamente o francês e o italiano. Não obstante, bebeu da fonte da commom law em alguma medida nosso ramo publicista. Esse fenômeno fica evidente no primeiro período da República, onde se adotou a unicidade de jurisdição sob influência norte-americana. Houve positivação de tal tendência no Decreto $\mathrm{n}^{\circ} 848$, de 1898 , onde se previa o uso da common law e equity na atividade jurisdicional pátria. Nessa realidade a Administração foi submetida ao controle jurisdicional. Esses fatos dão sentido à força que a jurisprudência obteve na evolução do Direito Administrativo brasileiro e também em outros ramos do Direito.

Numa também forte corrente influenciadora, o Direito Administrativo francês exportou para o nosso ordenamento concepções basilares como o ato administrativo, o conceito de serviço público, as prerrogativas da Administração, a teoria dos contratos administrativos e o fundamental princípio da legalidade.

O direito ítalo colaborou com os doutrinadores pátrios no conceito de mérito, de autarquias, de interesse público e, ao lado dos alemães, por um desenvolvimento técnico-científico do Direito Administrativo.

Já no século XX, uma nova influência da common law é verificada, e essa contribui fortemente para a criação das agencias reguladoras e a teoria da regulação. A doutrina social da Igreja também inseminou nosso Direito através da inspiração da função social da propriedade, que originou a desapropriação sancionatória. 
O Direito é vivo e, como todo organismo vivente, passa por transformações. Vamos tentar elencar aqui as mais recentes tendências do Direito Administrativo brasileiro, ainda que de forma sucinta.

O fenômeno jurídico de maior reflexo na seara juspublicista foi a promulgação da Constituição Brasileira de 1988. O advento dos princípios do Estado Democrático de Direito, sob inspiração neoliberal e sob forte influência da globalização, a (nova) influência da common law e do direito comunitário europeu, dos princípios da ciência econômica e da ciência da administração significaram profunda modificação no Direito Administrativo pátrio. Dessas inovações surgem entusiastas do chamado direito administrativo econômico, uma parte do Direito Administrativo mais voltado para as questões da ordem econômica e do interesse individual.

Há como tendência verificada na doutrina e na jurisprudência tais sintomas: I) alargamento do princípio da legalidade - com a adoção dos princípios do Estado Democrático de Direito houve uma maior limitação à discricionariedade administrativa como consequência da submissão da Administração aos princípios e valores e uma ampliação do controle judicial; II) fortalecimento da Democracia participativa - a previsão de instrumentos de participação do cidadão na gestão e no controle da atividade administrativa, notadamente o direito à informação (artigo $5^{\circ}$, XXXIII), a possibilidade de comunicar irregularidade ao Tribunal de Contas (artigo $74, \S 2^{\circ}$ ), a gestão participativa da seguridade social (artigo 194, VII), a gestão democrática da saúde e do ensino (artigos 198, III e 206, VI), dentre outros dispositivos, imprimiu forte tendência democrática e inclusiva na gerência estatal; III) processualização do direito administrativo - verificada por meio da incidência do princípio do devido processo legal no âmbito administrativo e as consequências dele decorrentes, como a obrigatória observância do contraditório, ampla defesa, recorribilidade e publicidade; IV) ampliação da discricionariedade 
administrativa - a discricionariedade pode ser definida como a faculdade que a lei confere à Administração para atuar sobre o caso concreto, segundo os critérios da oportunidade e conveniência. Tal conceito se alterou no desenrolar da história e teve evolução paralela ao princípio da legalidade. A equação é de que quanto mais se amplie o conceito de legalidade mais se restringe a discricionariedade. No ambiente liberal o Estado experimentou grande discricionariedade administrativa, situação alterada com o Estado Democrático de Direito, onde a Administração não se sujeita apenas à lei, mas ao próprio Direito. Colocam-se em posições contrárias nessa tendência duas correntes: os neoliberais que propugnam a ampliação da discricionariedade com inspiração no direito estrangeiro sob o argumento de que há necessidade de se promover uma transição da Administração burocrática para a Gerencial; e os conservadores, aderentes ao Direito positivo e a Constituição, numa busca pela máxima observância do princípio da legalidade e defesa da força normativa dos princípios na atividade legislativa e administrativa; V) revisão da noção de serviço público - se constituiu numa tendência de transformar serviços públicos prestados exclusivamente pelo Estado em atividades abertas à iniciativa privada sob a égide da livre iniciativa e da livre concorrência. Tem como fonte o direito comunitário europeu, mas também de uma interpretação do artigo 170, caput e inciso IV da Carta de 1988. No velho continente ocorreu uma transição da noção de serviço público para serviço de interesse econômico geral. No Brasil a corrente adepta ao neoliberalismo prega a adoção dessa mudança de concepção, porém, tal transição é de enorme dificuldade tendo em vista que a Carta vigente prevê atuação exclusiva do Estado para o exercício de várias atividades, como nos artigos 21, XI e XII e 175, VI; agencificação e função regulatória - As chamadas agências ou, mais tecnicamente, agências reguladoras com natureza de autarquias de regime especial, é uma realidade que se pôs ao lado de outras funções administrativas. A origem do conceito deriva da common law, de forte influência da experiência norte-americana. A ausência de previsão da 
delegação normativa às agências na Constituição cria um ambiente de dificuldade para o pleno funcionamento das mesmas no Brasil, embora existam diversas autarquias exercendo a função reguladora no país; VII) aplicação do princípio da subsidiariedade - suas consequências objetivas seriam a privatização das empresas estatais, privatização de atividades antes consideradas serviços públicos, ampliação da atividade de fomento, ampliação das formas de parceria do setor público com o privado e crescimento do terceiro setor. Duas são as bases teóricas para a adoção da referida tendência. Em primeiro lugar o entendimento de que há uma primazia do particular sobre o Estado e, em segundo, a ideia de que o Estado deve abster-se de explorar atividades que o particular tem a possibilidade de exercer, privilegiando a livre iniciativa. No histórico das Constituições pátrias há duas positivações acerca do princípio da subsidiariedade. Na Carta de 1967 e no artigo 173, caput, da Constituição cidadã. Os defensores da tendência em tela buscam o esvaziamento do Estado quanto ao seu papel de empresário. VIII) instauração da administração pública gerencial - apesar de possuir previsão legal, instituída pela Emenda Constitucional n 19 - Reforma Administrativa - a não edição da lei prevista no artigo $37, \S 8^{\circ}$ da Constituição impõe grande dificuldade à sua realização. A chamada "administração pública gerencial" se sedimentaria na maior discricionariedade administrativa, substituição do controle formal pelo controle de resultados, autonomia administrativa, financeira e orçamentária através do instrumento "contrato de gestão". IX) esvaziamento do princípio da supremacia do interesse público - seja da perspectiva de eliminação ou reconstrução, alega-se uma pretensa inviabilidade em se falar de supremacia do interesse público sobre o particular. Alguns também propõem a substituição do princípio em tela pelo princípio da razoabilidade. Óbice fundamental se põe diante da referida tentativa, já que o interesse público constitui o próprio fundamento das quatro funções administrativas: serviço público, fomento, polícia administrativa e intervenção; $\mathrm{X}$ ) restrição (ou diminuição) da incidência do 
Direito Administrativo - tendência que não tem como concretizar-se com extensão vista a natureza Constitucional das normas básicas de Direito Administrativo. Não obstante, há um caminhar rumo ao direito privado em alguns aspectos em que se submete a própria Administração Pública, como as áreas licitatória, contratual, quanto aos certames públicos, orçamento e contabilidade pública. Como exemplo, parte da doutrina é favorável ao fim do regime público dos contratos administrativos, mais especificamente naquilo que tange às clausulas exorbitantes. De fato, a Administração não deixou de lançar mão do direito privado. $\mathrm{Na}$ celebração de contratos privados, na gestão de suas empresas públicas, na contratação de servidores sob o regime celetista etc. por maior que seja a tentativa do afastamento da incidência das normas publicistas, essa nunca será total, pois mesmo quando a Administração recorre ao direito privado as normas deste são derrogadas pelo direito público.

\section{CAPÍTULO IV - A ADMINISTRAÇÃO PÚBLICA NA CONSTITUIÇÃO DE 1988}

A promulgação da Carta Constitucional de 1988, popularmente conhecida como "Constituição Cidadã 76 ", deu novo status ao Direito Administrativo brasileiro e, por consequência, à Administração Pública pátria. A Constituição serve no corrente período constitucionalista como fonte máxima e abrangente para a gestão de tudo aquilo ao qual se atribui a qualidade de público. Para tal, o constituinte originário previu parte de dedicação exclusiva à seara no corpo constitucional, no Capítulo VII, sob o título "Da Administração Pública". No presente fragmento monográfico vamos nos dedicar ao tema como disposto na Carta Magna nacional.

A Administração Pública pode ser sinteticamente definida como o conjunto de meios institucionais, materiais, financeiros e humanos

\footnotetext{
${ }^{76}$ CÂMARA DOS DEPUTADOS, Constituição Federal - 25 anos. Disponível em: $<\mathrm{http} / / /$ www2.camara.leg.br/atividadelegislativa/legislacao/Constituicoes_Brasileiras/constituicao-cidada> Acesso em: 26 de Outubro de 2014.
} 
preordenados à execução de decisões políticas. Nota-se na referida definição uma noção de subordinação da Administração ao Poder político. Também se depreende que esta é meio para o atingimento de determinados fins, tendo seus aspectos subjetivo e objetivo. $\mathrm{O}$ primeiro como as operações e atividades administrativas, o segundo como um conjunto de órgãos a serviço do Poder político. O artigo 37 da Constituição engloba os dois sentidos, Administração Pública como um conjunto orgânico e como atividade administrativa ${ }^{77}$.

Sobre a Administração direta, indireta e fundacional, destacamos que tal classificação é oriunda da possibilidade de descentralização administrativa. Administração direta diz respeito à administração centralizada, como conjunto de órgãos administrativos subordinados diretamente ao Poder Executivo (daí a nomenclatura). Por Administração indireta se entende a Administração descentralizada, como órgãos integrados nas muitas entidades personalizadas de prestação de serviço ou exploração de atividades de natureza econômica, ainda vinculadas ao Poder Executivo. A Constituição considera entidades da administração indireta as autarquias, as empresas públicas e as sociedades de economia mista. As fundações instituídas e mantidas pelo Poder Público compõem a Administração funcional. A previsão constitucional é de que somente por meio de lei específica poderá ser criada autarquia e autorizada a instituição de empresa pública, de sociedade de economia mista e de fundações, cabendo à lei complementar, no caso das fundações, definir as áreas de atuação fundacional ${ }^{78}$.

A nova ordem constitucional previu a participação do usuário na Administração Pública. Tal princípio foi instituído no bojo da Emenda Constitucional $n^{\circ} 19$, se positivando no $\$ 3^{\circ}$ do artigo 37. A Carta exige

\footnotetext{
${ }^{77}$ SILVA, José Afonso da. Manual da Constituição de 1988. São Paulo: Malheiros Editores, 2002, p. 101.

${ }^{78}$ Ibid., p. 102.
} 
edição de lei para a concretude da participação prevista, o que infelizmente ainda não ocorreu ${ }^{79}$.

Quanto à improbidade administrativa, é forma de moralidade administrativa que mereceu especial consideração do constituinte. Há previsão de punição do ímprobo com a suspensão dos seus direitos políticos, como prevê o $\S 4^{\circ}$ do artigo 37. A probidade administrativa é o dever de o funcionário servir a Administração com honestidade, sem favorecimentos pessoais ou de terceiros. Podemos definir a improbidade administrativa como uma imoralidade qualificada pela ocorrência de dano ao erário público ${ }^{80}$.

A Constituição não admite prazos indefinidos ou eternos para aplicação de pena. É por isso que previu a prescrição de sanções por atos ilícitos de agentes públicos. A lei estabelecerá tais prazos, que é o lapso de tempo dentro do qual a Administração pode punir o agente que tenha praticado o ilícito. Decorrido o prazo prescricional a Administração não pode mais punir o Agente. Não obstante, é facultado à Administração mover ação de ressarcimento de prejuízo que tenha provindo da prática ilícita $^{81}$.

Foi consagrado pelo constituinte originário o princípio da responsabilidade civil da Administração. Responsabilidade civil corresponde à obrigação de reparar os danos ou prejuízos de natureza patrimonial e moral. $\mathrm{O} \S 6^{\circ}$ do artigo 37 é o alicerce do referido princípio. Não há campo discricionário para cogitar a existência ou não de culpa ou dolo do agente para caracterizar o direito subjetivo do prejudicado à reparação do dano. Consagra-se, portanto, a teoria do risco administrativo ${ }^{82}$.

\footnotetext{
${ }^{79}$ SILVA, José Afonso da. Manual da Constituição de 1988. São Paulo: Malheiros Editores, 2002, p. 106.

${ }^{80}$ Ibid.

${ }^{81}$ Ibid., p 107.

${ }^{82}$ Ibid.
} 
Acrescido com o advento da reforma administrativa constante da Emenda Constitucional $n^{\circ} 19$, prevê o $\$ 8$ do artigo 37 a denominada autonomia gerencial ${ }^{83}$. Criou-se através do dispositivo em tela uma espécie de contrato administrativo, a ser celebrado entre administradores de órgãos do poder público e o próprio poder público. A previsão constitucional carece de edição de lei que estabelecerá os mecanismos de operação do instituto, não tendo sido emanado do Congresso diploma legal nesse sentido $^{84}$.

$\mathrm{Na}$ hipótese de servidores investidos em cargos eletivos, a Lei Fundamental garante o exercício do mandato e especifica seus efeitos. Em se tratando de mandato eletivo federal, estadual ou distrital o servidor ficará afastado do seu cargo, emprego ou função automaticamente (artigo 38, I). Nessas hipóteses o afastamento é com prejuízo dos vencimentos, na ausência de autorização constitucional para opção entre vencimentos e remuneração do mandato. Se a investidura for no mandato de Prefeito, haverá afastamento do servidor do cargo, emprego ou função sendo-lhe facultado optar pela sua remuneração. Caso a investidura do servidor se dê no mandato de Vereador, havendo compatibilidade de horário, exercerá cumulativamente o mandato com o cargo, emprego ou função. Nessa hipótese há cumulação entre os vencimentos (do cargo, emprego ou função) e a remuneração do mandato. Sendo as atividades incompatíveis em seus expedientes, ficará o servidor afastado e este poderá optar pelos vencimentos da sua situação funcional ou a remuneração do mandato. Há cômputo, para todos os efeitos legais, do tempo em que o servidor ficou no exercício do mandato eletivo, excetuando-se a promoção por merecimento $(\operatorname{artigo} 38, \mathrm{IV} \text { e } \mathrm{V})^{85}$.

Outra grande parte da organização administrativa diz respeito aos servidores públicos. A estes a Constituição dedicou extensa minudência.

\footnotetext{
${ }^{83}$ Para mais detalhes acerca do tema remetemos o leitor à página $\mathrm{n}^{\circ} 38$ do presente trabalho.

${ }^{84}$ SILVA, José Afonso da. Manual da Constituição de 1988. São Paulo: Malheiros Editores, 2002, p. 108.

${ }^{85}$ Ibid., p 109.
} 
Quanto aos agentes públicos, vale destacar que o Estado se exprime por meio dos seus órgãos, vias de ação pelos quais se coloca em condições de atuação e relacionamento com outros sujeitos de Direito. São justamente os agentes o elemento subjetivo dos órgãos públicos.

Os agentes públicos se distinguem de acordo com suas competências e atribuições. Podem ser agentes políticos, titulares de cargos que compõem a estrutura fundamental do governo, e agentes administrativos, titulares de cargo, emprego ou função pública, abarcando todos aqueles que possuem com o Poder Público relação não eventual de trabalho sob vínculo de dependência, profissionalidade e subordinação hierárquica.

Os agentes administrativos são categorizados em dois grupos. Os servidores públicos, que compreendem quatro espécies, de acordo com o artigo 37, I e IX. Servidores investidos em cargos (funcionários públicos); servidores públicos investidos em empregos (empregados públicos); servidores admitidos em funções públicas (servidores públicos em sentido estrito); e servidores contratados por tempo determinado (prestacionistas de serviço público temporário). De outro lado, há os militares. Estes são os membros das Polícias Militares e Corpos de Bombeiros Militares (artigo 42) e os das Forças Armadas (artigo 142, § $3^{\circ}$ ). Houve erradicação das terminologias "servidores civis" e "servidores militares" nos termos da Emenda Constitucional ${ }^{\circ} 18^{86}$.

O constituinte regulamentou o acesso à função administrativa. Esta é exercida por agentes administrativos, ou seja, por servidores públicos mediante a ocupação de um cargo, emprego, função pública ou por contratação. Exercer uma dessas posições é ter acesso à função administrativa para desempenhar atividade ou prestar serviços à Administração como servidor público. A Constituição prescreve que "os cargos, empregos e funções são acessíveis aos brasileiros que preencham os

\footnotetext{
${ }^{86}$ SILVA, José Afonso da. Manual da Constituição de 1988. São Paulo: Malheiros Editores, 2002, p. 110 .
} 
requesitos estabelecidos em lei, assim como aos estrangeiros, na forma da lei" (artigo 37, I). O princípio da acessibilidade busca a realização do princípio do mérito, que se materializa por meio da realização de certame público compatível com a complexidade e natureza do cargo ou emprego. Há, no entanto, previsão Constitucional de exceção à referida regra. É o caso dos cargos de livre nomeação e exoneração, previstos no artigo 37, II; e das funções de confiança, previstos no artigo 37, V. Numa postura de fomento à inclusão, a Carta prevê que a Administração preencha certa percentagem de cargos e empregos por pessoas com necessidades especiais, como estatui o artigo 37, VIII. A contratação de pessoal temporário é tema tratado no inciso IX do artigo 37. Aqui se verifica uma forma de prestação de serviço público que se diferencia do exercício do cargo ou função, sendo o contratado um prestacionista de serviços temporários. ${ }^{87}$

Pari passu à regulamentação da acessibilidade dos cidadãos ao corpo funcional administrativo, tratou o constituinte do sistema remuneratório dos agentes públicos. A Carta foi modificada pela Emenda Constitucional n ${ }^{\circ} 19$ que criou as espécies remuneratórias: o subsídio, o vencimento (singular), os vencimentos (plural) e a remuneração. O subsídio pode ser obrigatório, como no caso dos detentores de mandato eletivo, Ministros de Estado, Secretários de Estado e de Municípios, membros do Poder Judiciário, membros dos Tribunais de Contas, membros dos Ministérios Públicos, da Advocacia Geral da União, para Procuradores de Estado e do Distrito Federal, Defensores Públicos e servidores policiais. É facultativo como forma de remuneração dos servidores públicos organizados em carreira, se assim dispuser a lei, como estabelece o artigo $39, \S 8^{\circ}$. O subsídio fixa-se em parcela única, sendo vedado o acréscimo de qualquer outra espécie remuneratória (artigo 39, §4º ).

Vencimento e remuneração dos servidores são espécies remuneratórias gerais, aplicáveis aos casos em que a lei não prevê

\footnotetext{
${ }^{87}$ SILVA, José Afonso da. Manual da Constituição de 1988. São Paulo: Malheiros Editores, 2002,
} p. 111 . 
remuneração na forma de subsídio. Os termos vencimento (singular), vencimentos (plural) e remuneração não são termos unívocos. Vencimento (singular) é a retribuição do funcionário pelo exercício do cargo, emprego ou função correspondente ao grau, nível, símbolo ou padrão, fixado em lei. Vencimentos significa dizer que o agente público percebe o subsídio, como descrito acima, somado às vantagens pecuniárias fixas. Remuneração faz correspondência com a retribuição devida ao agente público composta de uma parte fixa e uma variável. Observe que a Constituição no artigo 37, XI, instituiu um limite remuneratório aos agentes públicos. ${ }^{88}$

Não obstante a limitação remuneratória presente no dispositivo supracitado, o constituinte previu também a vedação ao acúmulo de cargos, funções e empregos da Administração direta ou indireta. Essa é a inteligência do artigo 37, incisos XVI e XVII. Há, contudo, exceções específicas. Autoriza a Carta o acúmulo de dois cargos de professor; um cargo de professor com outro técnico ou científico; e dois cargos ou empregos privativos de profissionais da saúde. Só é lícita, por dedução lógica, o acumulo que se der com compatibilidade de horário. Da mesma forma é vedada a percepção de proventos oriundos de aposentadoria, (artigos 40; 42; e 142), com a remuneração de cargo, emprego ou função pública, excetuadas as hipóteses já apresentadas: os cargos eletivos, os cargos em comissão de livre nomeação e exoneração, observado o teto constitucional imposto pelo artigo $37, \mathrm{XI}^{89}$

A questão previdenciária dos agentes públicos não poderia passar in albis na previsão da organização administrativa constitucional. São hipóteses de aposentadoria: a invalidez permanente; compulsoriamente, aos setenta anos de idade; e voluntariamente, nos termos do artigo $40, \S 1^{\circ}$, III. Quanto aos ocupantes de cargo de provimento em comissão, de outros cargos temporários ou de emprego público, a Constituição previu a sujeição

\footnotetext{
${ }^{88}$ SILVA, José Afonso da. Manual da Constituição de 1988. São Paulo: Malheiros Editores, 2002, p. 116.

${ }^{89}$ Ibid., p. 117.
} 
desses ao regime geral da previdência social, segundo o artigo 40, §13 c/c artigo 201. O pensionamento possui previsão no parágrafo sétimo do artigo 40, e este será idêntico ao valor dos proventos a que teria direito o servidor em atividade na data de seu falecimento. ${ }^{90}$

O advento da Emenda Constitucional $n^{\circ} 19$ deu nova redação ao artigo 41, gerando reflexos na forma de aquisição da estabilidade do servidor. Note-se que pela redação do referido dispositivo apenas os servidores efetivos estão aptos à aquisição da estabilidade. São requisitos para concessão de estabilidade ao servidor: a nomeação por concurso para cargo de provimento efetivo e o exercício efetivo por mais de três anos (três anos e um dia). Destacamos que o termo inicial para a contagem do prazo se dá a partir da entrada em exercício do servidor.

Ao lado da estabilidade se encontra a vitaliciedade. Esta última é característica que a Constituição atribui a alguns agentes públicos, como os Magistrados, membros dos Tribunais de Contas e membros do Ministério Público. Vitaliciedade do agente público significa dizer que este tem o direito de permanecer por toda vida ou até que se aposente compulsoriamente no cargo que exerce. Como não há no ordenamento previsão do exercício de direitos absolutos, a vitaliciedade pode ser afastada pela extinção do cargo ou demissão decorrente de sentença judicial transitada em julgado ${ }^{91}$.

A Constituição, como berço de direitos e garantias, cobriu com seu manto protetivo os agentes públicos sob diversos direitos sociais, dentre os quais: a livre sindicalização, nos termos do artigo 37, VI; direito de greve, nos termos do artigo 37, VII (pendente de regulamentação por lei); salário mínimo, como consta do artigo $7^{\circ}$, IV; irredutibilidade de salários, como consta do artigo 37, XV; garantia de salário nunca inferior ao mínimo, artigo $7^{\circ}$, VII; décimo terceiro salário, artigo $7^{\circ}$, VIII; remuneração ou

\footnotetext{
${ }^{90}$ SILVA, José Afonso da. Manual da Constituição de 1988. São Paulo: Malheiros Editores, 2002, p. 121.

${ }^{91}$ Ibid., p. 124.
} 
subsídio do trabalho noturno superior à do diurno, artigo $7^{\circ}$, IX; saláriofamília, artigo $7^{\circ}$, XII; duração do trabalho não superior à oito horas diárias e quarenta e quatro semanais, artigo $7^{\circ}$, XIII; repouso semanal remunerado, artigo $7^{\circ}, \mathrm{XV}$; remuneração do serviço extraordinário com majoração mínima de $50 \%$ da remuneração, artigo $7^{\circ}$, XVI; férias remuneradas, artigo $7^{\circ}$, XVII; licença à gestante, artigo $7^{\circ}$, XVIII; licença-paternidade, artigo $7^{\circ}$, XIX; proteção do mercado de trabalho feminino, artigo $7^{\circ}, \mathrm{XX}$; redução de riscos, artigo $7^{\circ}, \mathrm{XXII}$; adicional de remuneração para atividades penosas, insalubres ou perigosas, artigo $7^{\circ}, \mathrm{XXIII}$; vedação à discriminação, artigo $7^{\mathrm{o}}, \mathrm{XXX}^{92}$

Quanto aos agentes públicos militares, membros das Polícias Militares e Corpos Militares dos estados-membros e do Distrito Federal, se aplicam as disposições do artigo $14, \S 8^{\circ}$ (do exercício dos direitos políticos) e do artigo $40, \S 9^{\circ}$ (cômputo do tempo de serviço). ${ }^{93}$

\section{1 - A EMENDA CONSTITUCIONAL № 19}

$\mathrm{O}$ constituinte originário previu mecanismos para a reforma constitucional, notadamente a revisão $o^{9495}$ e a emenda ${ }^{96} 97$.

\footnotetext{
${ }^{92}$ SILVA, José Afonso da. Manual da Constituição de 1988. São Paulo: Malheiros Editores, 2002, p. 125.

${ }^{94}$ Ato das Disposições Constitucionais Transitórias - Artigo $3^{\circ}$ - A revisão constitucional será realizada após cinco anos, contados da promulgação da Constituição, pelo voto da maioria absoluta dos membros do Congresso Nacional, em sessão unicameral.

${ }^{95}$ BONAVIDES, Paulo. Curso de direito constitucional. 29a ed. São Paulo: Malheiros Editores, 2014, p. 682.

${ }^{96}$ Constituição da República Federativa do Brasil de 1988 - Artigo 60. A Constituição poderá ser emendada mediante proposta:

I - de um terço, no mínimo, dos membros da Câmara dos Deputados ou do Senado Federal;

II - do Presidente da República;

III - de mais da metade das Assembléias Legislativas das unidades da Federação, manifestando-se, cada uma delas, pela maioria relativa de seus membros.

$\S 1^{\circ}$ - A Constituição não poderá ser emendada na vigência de intervenção federal, de estado de defesa ou de estado de sítio.

$\S 2^{\circ}$ - A proposta será discutida e votada em cada Casa do Congresso Nacional, em dois turnos, considerando-se aprovada se obtiver, em ambos, três quintos dos votos dos respectivos membros. $\S 3^{\circ}$ - A emenda à Constituição será promulgada pelas Mesas da Câmara dos Deputados e do Senado Federal, com o respectivo número de ordem.

$\S 4^{\circ}$ - Não será objeto de deliberação a proposta de emenda tendente a abolir:

I - a forma federativa de Estado;
} 
Quanto ao poder constituinte derivado, anota o constitucionalista mineiro acerca do poder de emenda à Constituição:

"A Constituição, como se vê, conferiu ao Congresso Nacional a competência para elaborar emendas a ela. Deu-se, assim, a um órgão constituído o poder de emendar a Constituição. Por isso se lhe dá a denominação de poder constituinte instituído ou constituído. Por outro lado, como esse seu poder não lhe pertence por natureza, primariamente, mas, ao contrário, deriva de outro (isto é, do poder constituinte originário), é que também se lhe reserva o nome de poder constituinte derivado, embora pareça mais acertado falar em competência constituinte derivada ou constituinte de segundo grau. Trata-se de um problema de técnica constitucional, já que seria muito complicado ter que convocar o constituinte originário todas as vezes em que fosse necessário emendar a Constituição. Por isso, o próprio poder constituinte originário, ao estabelecer a Constituição Federal, instituiu um poder constituinte reformador, ou poder de reforma constitucional, ou poder de emenda constitucional ${ }^{98}$,

Dentre os muitos ciclos de emenda à Constituição de $1988^{99}$, houve a Emenda n ${ }^{\circ} 19$, sob a ementa: "modifica o regime e dispõe sobre princípios e normas da Administração Pública, servidores e agentes políticos, controle de despesas e finanças públicas e custeio das atividades a cargo do Distrito Federal e dá outras providências". No conteúdo dos seus 34 artigos, a emenda sob lume introduziu uma modificação que para nós é de extrema significância: elencou explicitamente o princípio da eficiência no caput do artigo $37^{100}$.

Dessa forma a Emenda Constitucional $\mathrm{n}^{\mathrm{o}} 19 \mathrm{fez}$ com que a Carta dispusesse de uma previsão explícita, poupando o intérprete do exercício de hermenêutica teleológica para afirmar ser existente um princípio da boa

II - o voto direto, secreto, universal e periódico;

III - a separação dos Poderes;

IV - os direitos e garantias individuais.

$\S 5^{\circ}$ - A matéria constante de proposta de emenda rejeitada ou havida por prejudicada não pode ser objeto de nova proposta na mesma sessão legislativa.

${ }^{97}$ SILVA, José Afonso da. Curso de direito constitucional positivo. $34^{\mathrm{a}}$ ed. São Paulo: Malheiros Editores, 2010, p. 64.

${ }^{98}$ SILVA, José Afonso da. Curso de direito constitucional positivo. $34^{\mathrm{a}}$ ed. São Paulo: Malheiros Editores, 2010, p. 65.

${ }^{99} \mathrm{~A}$ última Emenda Constitucional aprovada é a de no 83, de 5.8.2014.

${ }^{100}$ Emenda Constitucional $N^{\circ} 19$, de 04 de Junho de 1998 - Artigo $3^{\circ}$ - O caput, os incisos I, II, V, VII, X, XI, XIII, XIV, XV, XVI, XVII e XIX e o $\$ 3^{\circ}$ do art. 37 da Constituição Federal passam a vigorar com a seguinte redação, acrescendo-se ao artigo os $\S \S 7^{\circ}$ a $9^{\circ}$ :

"Art. 37. A administração pública direta e indireta de qualquer dos Poderes da União, dos Estados, do Distrito Federal e dos Municípios obedecerá aos princípios de legalidade, impessoalidade, moralidade, publicidade e eficiência e, também, ao seguinte: (omissis)". 
administração ${ }^{101}$ no ordenamento jurídico. Fez o constituinte derivado verdadeiro "registro de nascimento" do principio que há muito alambrava o Direito Administrativo.

No próximo estágio do nosso percurso argumentativo, dedicaremos diminutas linhas ao estudo dos princípios administrativos coirmãos ao da eficiência, enunciados normativos que, como se constatará, não atuam de forma estanque, mas conjuntamente e de forma inter-relacionada.

\section{2 - PRINCÍPIOS DA ADMINISTRAÇÃO PÚBLICA}

No presente capítulo vamos discorrer acerca dos princípios que compõem o conjunto normativo que orienta o Direito Administrativo brasileiro. Vale destacar que não se faz exaustiva a listagem apresentada. Também nisso diverge a doutrina, elencando cada jurista princípios explícitos e implícitos que este julga pertinentes. A Constituição, por seu turno, positivou no caput do artigo 37 cinco princípios (legalidade, impessoalidade, moralidade, publicidade e eficiência). O legislador ordinário os desdobrou em onze (legalidade, finalidade, motivação, razoabilidade, proporcionalidade, moralidade, ampla defesa, contraditório, segurança jurídica, interesse público e eficiência ${ }^{102}$ ). Na esteira de Bandeira de Mello ${ }^{103}$, convergimos para os seguintes:

I) Princípio da supremacia do interesse público ${ }^{104} 105106107108$ - o princípio em análise é princípio geral de Direito, inerente à sociedade. Não

\footnotetext{
${ }^{101}$ MELLO, Celso Antônio Bandeira de. Curso de Direito Administrativo. $31^{\mathrm{a}}$ ed. São Paulo: Malheiros Editores, 2014, p. 125.

${ }^{102}$ Artigo $2^{\circ}$, caput, da Lei 9.784, de 29 de Janeiro de 1999, cuja ementa é "regula o processo administrativo no âmbito da Administração Pública Federal”.

${ }^{103}$ MELLO, Celso Antônio Bandeira de. Curso de Direito Administrativo. $31^{\mathrm{a}}$ ed. São Paulo: Malheiros Editores, 2014, pp. 98 - 128.

${ }^{104}$ MEIRELLES, Hely Lopes. Direito Administrativo brasileiro. 40 a ed. atual. São Paulo: Malheiros Editores, 2014, p. 110.

${ }^{105}$ MELLO, Celso Antônio Bandeira de. Curso de Direito Administrativo. $31^{\text {a }}$ ed. São Paulo: Malheiros Editores, 2014, p. 99.

${ }^{106}$ DI PIETRO, Maria Sylvia Zanella. Direito Administrativo. $27^{\mathrm{a}}$ ed. São Paulo: Atlas, 2014, p. 65.

${ }^{107}$ CARVAlHO FILHO, José dos Santos. Manual de Direito Administrativo. 25 edição. São Paulo: Atlas, 2012, p. 32.
} 
se abriga em dispositivo específico, mas irradia sua normatividade por vários institutos, como a função social da propriedade, a defesa do consumidor e do meio ambiente, por exemplo. Na seara Administrativa, especificamente, podemos anotar o artigo $5^{\circ}$, XXIV e XXV como demonstração de sua influência, já que a desapropriação e a requisição são manifestações da supremacia do interesse público sobre o particular.

A referida supremacia confere à Administração a faculdade de impor aos particulares obrigações de forma unilateral. Nesse sentido, extrai-se do princípio em tela a autoexecutoriedade dos atos administrativos, esta sendo a exigibilidade inerente aos atos de Estado, podendo a Administração exigir seu cumprimento sem prévio socorro da via judicial.

Ainda em decorrência da supremacia do interesse público, se reconhece à Administração a autotutela de seus atos, podendo esta revogar seus atos inconvenientes ou inoportunos, além de impor-lhe o dever de anular ou convalidar os atos inválidos. Não se trata de um exercício de poder, mas de função, já que o titular do poder que reveste a Administração é o Povo. Assim sendo, há supremacia do interesse público quando este se vincula à finalidade constitucionalmente preestabelecida.

II) Princípios da legalidade, finalidade, razoabilidade $e$ proporcionalidade (artigos 5º, II; 37, caput; e 84 IV) 109110111112113114115 116117118119120121122123124125126127128 - o motivo pelo qual aglutinamos

\footnotetext{
${ }^{108}$ TANAKA, Sônia Yuriko Kanashiro. Direito Administrativo. São Paulo: Malheiros Editores, 2008 , p. 74.

${ }^{109}$ SILVA, José Afonso da. Aplicabilidade das normas constitucionais. $7^{\text {a }}$ ed. São Paulo: Malheiros Editores, 2007, p. 668.

${ }^{110}$ MENDES, Gilmar Ferreira; BRANCO, Paulo Gustavo Gonet. Curso de Direito Constitucional. $6^{a}$ ed. São Paulo: Saraiva, 2011, p. 860.

${ }^{111}$ SILVA NETO, Manoel Jorge. Curso de direito constitucional. $5^{\mathrm{a}}$ ed., Rio de Janeiro: Lumen Juris, 2009, p. 453.

${ }^{112}$ MEIRELLES, Hely Lopes. Direito Administrativo brasileiro. 40 a ed. atual. São Paulo: Malheiros Editores, 2014, p. 90.

${ }^{113}$ Ibid., p. 96.

${ }^{114}$ MELLO, Celso Antônio Bandeira de. Curso de Direito Administrativo. $31^{\text {a }}$ ed. São Paulo: Malheiros Editores, 2014, p. 102.

${ }^{115}$ MELLO, Celso Antônio Bandeira de. Curso de Direito Administrativo. $31^{\mathrm{a}}$ ed. São Paulo: Malheiros Editores, 2014, p. 109.

${ }^{116}$ Ibid., p. 111.
} 
os quatro princípios abordados num mesmo tópico é a sua íntima correlação. Um é desdobramento lógico do outro, como exporemos a seguir.

É no princípio da legalidade onde se configura o regime jurídicoadministrativo, sendo um princípio caracterizador do Estado Democrático de Direito. Dele resulta a submissão do Estado à Lei, tendo como consequência a atividade da Administração Pública de forma sublegal. O princípio da legalidade faz oposição a uma atuação personalista e autoritária da Administração, fazendo com que o atuar estatal dê-se dentro de um balizamento abstrato, previamente estabelecido, concretizando a própria soberania popular. Resumidamente, além de não poder atuar contra legem ou praeter legem, a Administração só pode agir secundum legem ${ }^{129}$.

Cumpre à Administração perseguir objetivos, fins. Esses se encontram no seio da norma, na sua teleologia. Daí a inerência do princípio da finalidade ao princípio da legalidade. Lançar mão de lei para a prática de ato administrativo e inobservar sua finalidade é desvirtuar a norma, acarretando a nulidade daquela ação. Aquele que desatenta às finalidades legais incorre em desvio de finalidade. Assim, anota o publicista paulista: “a finalidade legal é um elemento da própria lei, é justamente o fator que

\footnotetext{
${ }^{117}$ MELLO, Celso Antônio Bandeira de. Curso de Direito Administrativo. $31^{\text {a }}$ ed. São Paulo: Malheiros Editores, 2014, p. 113.

${ }^{118}$ DI PIETRO, Maria Sylvia Zanella. Direito Administrativo. $27^{\mathrm{a}}$ ed. São Paulo: Atlas, 2014, p. 64.

${ }^{119}$ Ibid., p. 80.

${ }^{120}$ CARVALHO FILHO, José dos Santos. Manual de Direito Administrativo. 25 ${ }^{\mathrm{a}}$ edição. São Paulo: Atlas, 2012, p. 19.

${ }^{121}$ Ibid., p. 39.

${ }^{122}$ Ibid., p. 41.

${ }^{123}$ ROCHA, Silvio Luís Ferreira da. Manual de Direito Administrativo. São Paulo: Malheiros Editores, 2013, p. 71.

${ }^{124}$ Ibid., pp. $86-87$.

${ }^{125}$ Ibid., p. 89.

${ }^{126}$ TANAKA, Sônia Yuriko Kanashiro. Direito Administrativo. São Paulo: Malheiros Editores, 2008, p. 68.

${ }^{127}$ Ibid., p. 72 .

${ }^{128}$ Ibid., p. 76.

${ }^{129}$ TASSINOPOULOS, MICHEL. Traité des Actes Administratifs, Athenas, Librairie Sirey, 1954, p. 69. apud MELLO, Celso Antônio Bandeira de. Curso de Direito Administrativo. $31^{\text {a }}$ ed. São Paulo: Malheiros Editores, 2014, p. 104.
} 
proporciona compreende-la. Por isso não se pode conceber o principio da legalidade sem encarecer a finalidade quer de tal principio em si mesmo, quer das distintas leis que se expressa ${ }^{130,}$.

Enquanto o princípio da finalidade se relaciona ao objeto, o princípio da razoabilidade diz respeito à forma, ao processo de atingimento daquele. Condutas bizarras, incoerentes, insensatas e imprudentes configuram-se desarrazoadas, portanto ilegítimas, passíveis de anulação por via judicial em razão da desatenção aos ditames legais de finalidade quanto ao objeto e ao modo de perseguição da prescrição legislativa.

Sobre o princípio da proporcionalidade, elucida-nos de forma brilhante o mestre: “(...) as competências administrativas só podem ser validamente exercidas na extensão e intensidade correspondentes ao que seja realmente demandado para cumprimento da finalidade de interesse público a que estão atreladas ${ }^{131}$ ". O principio aludido possui relação com o atuar necessário, condenando-se o excesso, o agravo inútil à perseguição dos fins legais. Serve o princípio como forma de contenção de possível arbitrariedade no exercício do poder administrativo, maculando de ilegitimidade o ato administrativo a ação desproporcional da Administração na realização de determinado objetivo. É um princípio que se aplica pari passu ao da razoabilidade.

Todos os princípios acima possuem fonte constitucional comum, tornando-os indivisíveis e congruentes entre si.

III) Princípio da motivação (artigos $1^{\circ}$, II e parágrafo único; e $5^{\circ}$ XXXV) ${ }^{132} 133 \quad 134 \quad 135136$ - a justificação dos atos administrativos se

\footnotetext{
${ }^{130}$ MELLO, Celso Antônio Bandeira de. Curso de Direito Administrativo. $31^{\mathrm{a}}$ ed. São Paulo: Malheiros Editores, 2014, p. 110.

${ }^{131}$ Ibid., p. 113.

${ }^{132}$ MEIRELLES, Hely Lopes. Direito Administrativo brasileiro. 40 a ed. atual. São Paulo: Malheiros Editores, 2014, p. 105.

${ }^{133}$ MELLO, Celso Antônio Bandeira de. Curso de Direito Administrativo. $31^{\text {a }}$ ed. São Paulo: Malheiros Editores, 2014, p. 115.

${ }^{134}$ DI PIETRO, Maria Sylvia Zanella. Direito Administrativo. $27^{\mathrm{a}}$ ed. São Paulo: Atlas, 2014, p. 82.
} 
consubstancia no apontamento da relação entre os fundamentos de direito e fato que levaram à tomada de determinada decisão. Tanto nos atos estritamente vinculados, cujo apontamento do dispositivo legal satisfaz a motivação, quanto em atos mais complexos, como no processo administrativo disciplinar que exige fundamentação mais detalhada, o referido princípio repousa na necessidade de justificar ao titular do Poder (o Povo) a razão do atuar administrativo. É pela fundamentação que embasa a motivação do ato administrativo, que se externaliza a observância dos princípios da legalidade, finalidade, razoabilidade e proporcionalidade.

IV) Princípio da impessoalidade (artigos 37, caput; e $5^{\mathbf{o}}$ caput) $)^{137} 138$ 139140141142143144145 - deriva da noção de igualdade e isonomia, valores indispensáveis à operação da relação Estado-cidadão, afastando a postura, já superada, Soberano-súdito, esta caracterizada pela confusão entre o patrimônio dos nobres e do Estado. A Constituição prevê explicitamente a aplicação do princípio da impessoalidade quando condiciona o acesso à função pública ao certame público. Também o faz na exigência de licitação para aquisição de bens e para a realização de concessões e permissões públicas.

\footnotetext{
${ }^{135}$ ROCHA, Silvio Luís Ferreira da. Manual de Direito Administrativo. São Paulo: Malheiros Editores, 2013, p. 83.

${ }^{136}$ TANAKA, Sônia Yuriko Kanashiro. Direito Administrativo. São Paulo: Malheiros Editores, 2008 , p. 75.

${ }^{137}$ SILVA, José Afonso da. Aplicabilidade das normas constitucionais. $7^{\text {a }}$ ed. São Paulo: Malheiros Editores, 2007, p. 668.

${ }^{138}$ MENDES, Gilmar Ferreira; BRANCO, Paulo Gustavo Gonet. Curso de Direito Constitucional. $6^{a}$ ed. São Paulo: Saraiva, 2011, p. 861.

${ }^{139}$ SILVA NETO, Manoel Jorge. Curso de direito constitucional. $5^{\text {a }}$ ed., Rio de Janeiro: Lumen Juris, 2009, p. 454.

${ }^{140}$ MEIRELLES, Hely Lopes. Direito Administrativo brasileiro. $40^{\text {a }}$ ed. atual. São Paulo: Malheiros Editores, 2014, p. 95.

${ }^{141}$ MELLO, Celso Antônio Bandeira de. Curso de Direito Administrativo. $31^{\text {a }}$ ed. São Paulo: Malheiros Editores, 2014, p. 117.

${ }^{142}$ DI PIETRO, Maria Sylvia Zanella. Direito Administrativo. $27^{\mathrm{a}}$ ed. São Paulo: Atlas, 2014, p. 68.

${ }^{143}$ CARVALHO FILHO, José dos Santos. Manual de Direito Administrativo. 25a edição. São Paulo: Atlas, 2012, p. 20.

${ }^{144}$ ROCHA, Silvio Luís Ferreira da. Manual de Direito Administrativo. São Paulo: Malheiros Editores, 2013, p. 73.

${ }^{145}$ TANAKA, Sônia Yuriko Kanashiro. Direito Administrativo. São Paulo: Malheiros Editores, 2008, p. 69.
} 
V) Princípio da publicidade (artigos 37, caput; 5, XXXIII e XXXIV, "b") 146147148149150151152153154 - cumpre ao Estado, num regime democrático alicerçado no Direito, que suas ações sejam transparentes e acessíveis. Ainda mais quando essa transparência e acessibilidade forem de pertinência ao interesse do particular individualmente considerado. O princípio da publicidade veio a ser regulamentado recentemente com a edição da Lei $\mathrm{n}^{\mathrm{o}} 12.527$ de 18.11.2011, que dita a forma de acesso à informação pública. No âmbito do Direito Administrativo o sigilo só é admitido nos termos do artigo $5^{\circ}$, XXXIII, ou seja, quando há imprescindibilidade de sigilo como forma de manutenção da segurança da Sociedade e do Estado.

VI) Princípios do devido processo legal e da ampla defesa (artigo $5^{\circ}$, LIV e LV) ${ }^{155156157}$ - com um passado recente que comporta um desonroso histórico de abusos, arbitrariedades e moléstia aos direitos mais fundamentais, não poderia se esperar outra coisa de uma Constituição democrática senão impor ao Estado brasileiro a observância inafastável dos princípios do devido processo legal e da ampla defesa.

\footnotetext{
${ }^{146}$ SILVA, José Afonso da. Aplicabilidade das normas constitucionais. $7^{\text {a }}$ ed. São Paulo: Malheiros Editores, 2007, p. 670.

${ }^{147}$ MENDES, Gilmar Ferreira; BRANCO, Paulo Gustavo Gonet. Curso de Direito Constitucional. $6^{a}$ ed. São Paulo: Saraiva, 2011, p. 863.

${ }^{148}$ SILVA NETO, Manoel Jorge. Curso de direito constitucional. $5^{\mathrm{a}}$ ed., Rio de Janeiro: Lumen Juris, 2009, p. 460.

${ }^{149}$ MEIRELLES, Hely Lopes. Direito Administrativo brasileiro. $40^{\mathrm{a}}$ ed. atual. São Paulo: Malheiros Editores, 2014, p. 97.

${ }^{150}$ MELLO, Celso Antônio Bandeira de. Curso de Direito Administrativo. 31 a ed. São Paulo: Malheiros Editores, 2014, p. 117.

${ }^{151}$ DI PIETRO, Maria Sylvia Zanella. Direito Administrativo. $27^{\text {a }}$ ed. São Paulo: Atlas, 2014, p. 72.

${ }^{152}$ CARVALHO FILHO, José dos Santos. Manual de Direito Administrativo. $25^{\mathrm{a}}$ edição. São Paulo: Atlas, 2012, p. 25.

${ }^{153}$ ROCHA, Silvio Luís Ferreira da. Manual de Direito Administrativo. São Paulo: Malheiros Editores, 2013, p. 77.

${ }^{154}$ TANAKA, Sônia Yuriko Kanashiro. Direito Administrativo. São Paulo: Malheiros Editores, 2008 , p. 70.

${ }^{155}$ MEIRELLES, Hely Lopes. Direito Administrativo brasileiro. $40^{\mathrm{a}}$ ed. atual. São Paulo: Malheiros Editores, 2014, p. 109.

${ }^{156}$ MELLO, Celso Antônio Bandeira de. Curso de Direito Administrativo. 31 a ed. São Paulo: Malheiros Editores, 2014, p. 118.

${ }^{157}$ ROCHA, Silvio Luís Ferreira da. Manual de Direito Administrativo. São Paulo: Malheiros Editores, 2013, p. 91.
} 
De origem história assentada nas conquistas de liberdade e justiça do povo britânico, o devido processo legal tem em sua versão original a denominação de due process of law e remonta à Magna Carta de 1215. É um princípio alastrado por todo o Direito e arraigado no seio da Democracia, servindo-se de forma à liberdade e a busca do justo. Sintetizou Jhering a sua importância ao afirmar que "inimiga jurada do arbítrio a forma é a irmã da liberdade ${ }^{158,}$.

VII) Princípio da moralidade administrativa (artigos 37, caput e $\$ 4^{\circ}$;

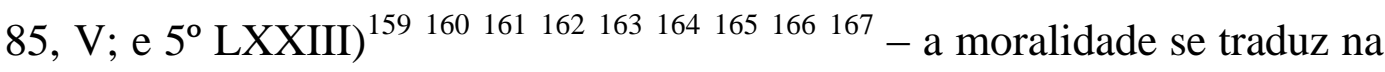
condução administrativa sob a égide da ética, compreendendo a lealde e a boa fé. Comportamentos distantes desses parâmetros são ilícitos, logo, passíveis de invalidação. O princípio impõe à Administração atividade coerente, sendo vedada modificação de entendimento anterior face ao caso in concretu. Cabe salientar aqui que o princípio não tem como fonte a moral comum, mas a moral acolhida pelas normas jurídicas.

VIII) Princípio do controle judicial dos atos administrativos (artigo $\left.5^{\circ}, \mathrm{XXXV}\right)^{168169170}$ - no Brasil adotamos a unicidade de jurisdição, ou seja,

\footnotetext{
${ }^{158}$ Jhering, R. von. L'espirit du Droit Romain. $3^{\text {a }}$ ed. Paris: Librairie Marescq Aîné, 1887, p. 164. apud MELLO, Celso Antônio Bandeira de. Curso de Direito Administrativo. 31 ad. São Paulo: Malheiros Editores, 2014, p. 122.

${ }^{159}$ SILVA, José Afonso da. Aplicabilidade das normas constitucionais. $7^{\text {a }}$ ed. São Paulo: Malheiros Editores, 2007, p. 669.

${ }^{160}$ MENDES, Gilmar Ferreira; BRANCO, Paulo Gustavo Gonet. Curso de Direito Constitucional. $6^{\mathrm{a}}$ ed. São Paulo: Saraiva, 2011, p. 862.

${ }^{161}$ SILVA NETO, Manoel Jorge. Curso de direito constitucional. $5^{\mathrm{a}}$ ed., Rio de Janeiro: Lumen Juris, 2009, p. 457.

${ }^{162}$ MEIRELLES, Hely Lopes. Direito Administrativo brasileiro. $40^{\mathrm{a}}$ ed. atual. São Paulo: Malheiros Editores, 2014, p. 91.

${ }^{163}$ MELLO, Celso Antônio Bandeira de. Curso de Direito Administrativo. 31 a ed. São Paulo: Malheiros Editores, 2014, p. 122.

${ }^{164}$ DI PIETRO, Maria Sylvia Zanella. Direito Administrativo. $27^{\text {a }}$ ed. São Paulo: Atlas, 2014, p. 77.

${ }^{165}$ CARVALHO FILHO, José dos Santos. Manual de Direito Administrativo. $25^{\mathrm{a}}$ edição. São Paulo: Atlas, 2012, p. 21.

${ }^{166}$ ROCHA, Silvio Luís Ferreira da. Manual de Direito Administrativo. São Paulo: Malheiros Editores, 2013, p. 75.

${ }^{167}$ TANAKA, Sônia Yuriko Kanashiro. Direito Administrativo. São Paulo: Malheiros Editores, 2008 , p. 70.

${ }^{168}$ MELLO, Celso Antônio Bandeira de. Curso de Direito Administrativo. 31 a ed. São Paulo: Malheiros Editores, 2014, p. 123.
} 
é inafastável à apreciação do judiciário lesão ou ameaça a direito. Portanto, possuímos na ordem constitucional vigente o monopólio da jurisdição pelo Poder Judiciário. Não há via alternativa para a apreciação de contendas que dê à sua respectiva decisão caráter de definitividade. É a referida jurisdição que imporá à Administração o Direito, seja pela anulação de seus atos inválidos, seja pela imposição de conduta adequada e condenação ao pagamento das indenizações devidas.

IX) Princípio da responsabilidade do Estado por atos administrativos (artigo 37, §6 $\left.{ }^{\circ}\right)^{171} 172173174$ - a Constituição de 1988 adotou o princípio em sua amplitude, sendo correto afirmar que a responsabilidade do Estado aplica-se a qualquer função pública, e não apenas aos danos provenientes dos atos administrativos. Não há que falar em dolo ou culpa, frente à responsabilidade objetiva adotada e imposta pelo constituinte ao Estado. Com a dicção do dispositivo constitucional conclui-se que a responsabilidade do estado se dá quanto às condutas comissivas, restando responsabilidade subjetiva apenas quando se configurarem os elementos: dever legal de agir; possibilidade de agir; ineficácia e intempestividade da ação. Aplica-se o princípio em tela às pessoas de direito privado que atuarem como prepostas do Estado no exercício de determinada atividade.

X) Princípio da segurança jurídica 175176177178179 - é fruto de todo o sistema constitucional. Não se abriga em um dispositivo determinado, mas

\footnotetext{
${ }^{169}$ DI PIETRO, Maria Sylvia Zanella. Direito Administrativo. $27^{\mathrm{a}}$ ed. São Paulo: Atlas, 2014, p. 70.

${ }^{170}$ ROCHA, Silvio Luís Ferreira da. Manual de Direito Administrativo. São Paulo: Malheiros Editores, 2013, p. 91.

${ }^{171}$ SILVA, José Afonso da. Aplicabilidade das normas constitucionais. $7^{\text {a }}$ ed. São Paulo: Malheiros Editores, 2007, p. 674.

${ }^{172}$ MENDES, Gilmar Ferreira; BRANCO, Paulo Gustavo Gonet. Curso de Direito Constitucional. $6^{\text {a }}$ ed. São Paulo: Saraiva, 2011, p. 867.

${ }^{173}$ MELLO, Celso Antônio Bandeira de. Curso de Direito Administrativo. $31^{\text {a }}$ ed. São Paulo: Malheiros Editores, 2014, p. 124.

${ }^{174}$ ROCHA, Silvio Luís Ferreira da. Manual de Direito Administrativo. São Paulo: Malheiros Editores, 2013, p. 92.

${ }^{175}$ MEIRELLES, Hely Lopes. Direito Administrativo brasileiro. 40 a ed. atual. São Paulo: Malheiros Editores, 2014, p. 103.

${ }^{176}$ MELLO, Celso Antônio Bandeira de. Curso de Direito Administrativo. $31^{\text {a }}$ ed. São Paulo: Malheiros Editores, 2014, p. 126.
} 
exala-se do próprio Direito. Numa sociedade que se organiza por meio de leis, é assegurado ao cidadão ter o conhecimento das consequências da sua conduta pela subsunção desta à norma. Essa é também uma função do próprio Direito, dar ao corpo social previsibilidade e, por via de consequência, estabilidade. Como manifestação concreta do principio da segurança jurídica podemos elencar os institutos da prescrição, da decadência, da preclusão, da usucapião, da irretroatividade da lei, o direito adquirido etc.

A segurança jurídica traz ao Estado desenvolvimento, pois, é calcado nela que o corpo social planeja e evolui. No que tange ao Direito Administrativo, esclarece o magistrado paulista:

"O princípio da segurança jurídica foi reconhecido expressamente pelo artigo $2^{\circ}$, caput, da Lei 9.784/1999, com o firme propósito de vedar a aplicação retroativa da nova interpretação de lei no âmbito da Administração Pública. Proibiu-se, com isso, que uma mudança de orientação, em caráter normativo, afetasse situações já reconhecidas e consolidadas na vigência de orientação anterior. Esse princípio não impede a Administração de anular atos praticados com a inobservância da lei, mas resguarda o administrado que teve seu direito reconhecido a partir de interpretação tida como correta pela Administração, que depois mudou de entendimento. ${ }^{180}$,

XI) Princípio da eficiência (artigo 37, caput) 181182183184185186187 188189190 - o referido princípio também é denominado princípio da boa

${ }^{177}$ DI PIETRO, Maria Sylvia Zanella. Direito Administrativo. $27^{\mathrm{a}}$ ed. São Paulo: Atlas, 2014, p. 85.

${ }^{178}$ CARVALHO FILHO, José dos Santos. Manual de Direito Administrativo. 25a edição. São Paulo: Atlas, 2012, p. 35.

${ }^{179}$ ROCHA, Silvio Luís Ferreira da. Manual de Direito Administrativo. São Paulo: Malheiros Editores, 2013, p. 93.

${ }^{180}$ Ibid.

${ }^{181}$ SILVA, José Afonso da. Aplicabilidade das normas constitucionais. $7^{\text {a }}$ ed. São Paulo: Malheiros Editores, 2007, p. 672.

${ }^{182}$ SILVA, José Afonso da. Manual da Constituição de 1988. São Paulo: Malheiros Editores, 2002, p. 104.

${ }^{183}$ MENDES, Gilmar Ferreira; BRANCO, Paulo Gustavo Gonet. Curso de Direito Constitucional. $6^{\mathrm{a}}$ ed. São Paulo: Saraiva, 2011, p. 866.

${ }^{184}$ SILVA NETO, Manoel Jorge. Curso de direito constitucional. $5^{\mathrm{a}}$ ed., Rio de Janeiro: Lumen Juris, 2009, p. 462.

${ }^{185}$ MEIRELLES, Hely Lopes. Direito Administrativo brasileiro. 40 ${ }^{\mathrm{a}}$ ed. atual. São Paulo: Malheiros Editores, 2014, p. 102.

${ }^{186}$ DI PIETRO, Maria Sylvia Zanella. Direito Administrativo. $27^{\mathrm{a}}$ ed. São Paulo: Atlas, 2014, p. 84.

${ }^{187}$ CARVAlHO FILHO, José dos Santos. Manual de Direito Administrativo. $25^{\text {a }}$ edição. São Paulo: Atlas, 2012, p. 29. 
administração ${ }^{191}$ e sobre ele nos aprofundaremos no tópico a seguir, onde teremos a oportunidade de explorar a sua definição sob a ótica de vários jurisconsultos.

\section{3 - O PRINCÍPIO DA EFICIÊNCIA}

Erigido ao patamar constitucional com relativa recência, o princípio da eficiência é norma que vincula o atuar estatal. Elencado nas mais diversas obras constitucionalistas e administrativas é por vezes definido rasamente, ao modo en passant. Por esse motivo, lançaremos mão dos mais consagrados doutrinadores para aglutinar suas expeditas considerações e buscar uma definição que dê amplitude e profundidade ao princípio que para nós é da mais extrema significância. $\mathrm{O}$ constitucionalista mineiro o definiria nas seguintes palavras:

“(...) o princípio da eficiência administrativa tem como conteúdo a relação meios e resultados. (...) a eficiência administrativa se obtém pelo melhor emprego dos recursos e meios (humanos, matérias, e institucionais) para melhor satisfazer às necessidades coletivas num regime de igualdade dos usuários ${ }^{192 \%}$.

Arremata o publicista:

"O princípio investe as regras de competência, pois o bom desempenho das atribuições de cada órgão ou entidade pública é fator de eficiência em cada área da função governamental. Mas investe também a atuação funcional, de sorte que todo agente público tem o dever de eficiência, que lhe impõe realizar suas atribuições com presteza, perfeição e rendimento funcional, não sendo suficiente desempenhar a atividade administrativa com legalidade e moralidade, exigindo-se resultados positivos para o serviço público e satisfatório atendimento das necessidades da comunidade e de seus membros"193.

\footnotetext{
${ }^{188}$ ROCHA, Silvio Luís Ferreira da. Manual de Direito Administrativo. São Paulo: Malheiros Editores, 2013, p. 80.

${ }^{189}$ TANAKA, Sônia Yuriko Kanashiro. Direito Administrativo. São Paulo: Malheiros Editores, 2008, p. 71.

${ }^{190}$ FERRAZ, Sérgio e DALLARI, Adilson Abreu. Processo administrativo. $3^{\mathrm{a}}$ ed. São Paulo: Malheiros Editores, 2001, p. 122.

${ }^{191}$ MELLO, Celso Antônio Bandeira de. Curso de Direito Administrativo. $31^{\text {a }}$ ed. São Paulo: Malheiros Editores, 2014, p. 125.

${ }^{192}$ SILVA, José Afonso da. Aplicabilidade das normas constitucionais. $7^{\text {a }}$ ed. São Paulo: Malheiros Editores, 2007, pp. 672 - 673.

${ }^{193}$ SILVA, José Afonso da. Manual da Constituição de 1988. São Paulo: Malheiros Editores, 2002, p. 104.
} 
Como vemos, é um princípio que permeia toda a função da Administração e de seus agentes, fazendo da eficiência não apenas um postulado, uma notícia, mas um critério que verdadeiramente se impõe a cada um que, revestido do poder delegado pelo povo, exerce a função administrativa.

Da busca do Estado moderno pela eficiência, anota o augusto jurista baiano:

"Deve ser ressaltada também a ligação existente entre os princípios da eficiência e da economicidade. Há, desde a Antiguidade, principalmente a partir dos estudos de Epicuro $^{194}$, corrente filosófica amparada na ideia de que cabe ao ser humano procurar, sempre, o maior prazer possível. É o hedonismo (do grego hedoné, que significa prazer). $\mathrm{O}$ hedonismo produz reflexos no contexto da atuação da Administração Pública, pois ao cometer ao ser humano a tarefa de prover as suas necessidades com a menor quantidade possível de esforço e sacrifício, impinge-a a realizar o máximo em termos de consecução do interesse público com o mínimo de dispêndio de tempo e de recursos, razão pela qual se vê conduzida pelo principio da economicidade, que outra coisa não é que o pensamento hedonista transportado para atuar administrativo. ${ }^{195}$,

Como combustível da máquina administrativa temos o erário público, razão pela qual é pertinente a leitura do princípio da eficiência não apenas como aquele que busca realizar o melhor resultado, mas, conjuntamente, aquele que realiza o melhor resultado com o menor dispêndio possível. Essa é uma das facetas de interpretação do princípio em tela, uma moralidade objetiva, cujo mérito não se abriga na forma de atuação somente, mas nos fins a que se propõe. Como sentencia Tanaka:

"A Administração e o administrador hão de atuar com observância à legalidade, impessoalidade, publicidade, mas também com eficiência. Portanto, administrar bem, com competência técnica, com capacidade de produzir resultados úteis e desejados ${ }^{196}$, é dever jurídico. Encontram-se na doutrina algumas referências a este princípio, aproximando-o da administração privada, de

\footnotetext{
${ }^{194}$ Epicuro de Samos (em grego antigo: 'E $\pi$ íkovpos, Epikouros, "aliado, camarada"; 341 a.C., Samos - 271 ou 270 a.C., Atenas) foi um filósofo grego do período helenístico. Seu pensamento foi muito difundido e numerosos centros epicuristas se desenvolveram na Jônia, no Egito e, a partir do século I, em Roma, onde Lucrécio foi seu maior divulgador.

${ }^{195}$ SILVA NETO, Manoel Jorge. Curso de direito constitucional. $5^{\mathrm{a}}$ ed., Rio de Janeiro: Lumen Juris, 2009, pp. 463 - 464.

${ }^{196}$ Lei n ${ }^{\circ} 8.987$, de 13 de Fevereiro de 1995 - "Dispõe sobre o regime de concessão e permissão da prestação de serviços públicos previsto no art. 175 da Constituição Federal, e dá outras providências." - Art. $6^{\circ}$ - Toda concessão ou permissão pressupõe a prestação de serviço adequado ao pleno atendimento dos usuários, conforme estabelecido nesta Lei, nas normas pertinentes e no respectivo contrato.
} 
natureza empresarial. Nós, diversamente, o vemos medularmente inserido no universo da gestão pública, dentro da concepção de Estado como responsável, direto e indireto, pelo bem comum, que vem a ser sua finalidade e, mesmo, razão de ser. (...) É de se arrematar, aqui, que, entre nós, não mais se trata de uma postulação, de uma aspiração, mas bem ao contrário, de um mandamento jurídico de índole constitucional. ${ }^{197, " ~(G r i f o ~ n o s s o) . ~}$

A Lei Fundamental, ao abrigar o princípio da eficiência através da intervenção do constituinte derivado em seu texto, passou também a buscar a sistematização do mesmo. Destacadamente se colocam em alinhamento principiológico os dispositivos artigo $37, \S 3^{\circ}$ e incisos ${ }^{198}$ e artigo $74, I I^{199}$. Evidencia-se, portanto, que a ordem constitucional não impôs apenas fins à Administração, mas previu um sistema de dispositivos com o objetivo de aferir o atingimento desses e reagir à sua não observação. Como agrupa Silvio Luís Ferreira da Rocha, compõe o referido sistema:

"Na Constituição visualizamos alguns institutos influenciados pelo princípio da eficiência, como: a profissionalização dos agentes públicos, pela exigência de realização de concurso público para provimento de cargos efetivos (art. 37, II); a otimização de gastos com pessoal, com o estabelecimento de limite

\footnotetext{
${ }^{197}$ TANAKA, Sônia Yuriko Kanashiro. Direito Administrativo. São Paulo: Malheiros Editores, 2008, p. $71-72$.

${ }^{198}$ Art. 37. A administração pública direta e indireta de qualquer dos Poderes da União, dos Estados, do Distrito Federal e dos Municípios obedecerá aos princípios de legalidade, impessoalidade, moralidade, publicidade e eficiência e, também, ao seguinte:
}

(omissis)

$\S 3^{\circ}$ A lei disciplinará as formas de participação do usuário na administração pública direta e indireta, regulando especialmente:

I - as reclamações relativas à prestação dos serviços públicos em geral, asseguradas a manutenção de serviços de atendimento ao usuário e a avaliação periódica, externa e interna, da qualidade dos serviços;

II - o acesso dos usuários a registros administrativos e a informações sobre atos de governo, observado o disposto no art. $5^{\circ}$, X e XXXIII; (Inciso regulamentado pela Lei $n^{\circ} 12.527$, de 2011).

III - a disciplina da representação contra o exercício negligente ou abusivo de cargo, emprego ou função na administração pública. (Grifo nosso).

${ }^{199}$ Art. 74. Os Poderes Legislativo, Executivo e Judiciário manterão, de forma integrada, sistema de controle interno com a finalidade de:

I - (omissis)

II - comprovar a legalidade e avaliar os resultados, quanto à eficácia e eficiência, da gestão orçamentária, financeira e patrimonial nos órgãos e entidades da administração federal, bem como da aplicação de recursos públicos por entidades de direito privado; (Grifo nosso). 
remuneratório conhecido como 'teto' (art. 37, XI); a participação do usuário na Administração direta e indireta (prevista no art. $37, \S 3^{\circ}$ ); a ampliação da autonomia gerencial, orçamentária e financeira de órgãos e entidades da Administração direta e indireta (art. $37, \S 8^{\circ}$ ); a gestão associada de serviços públicos (art. 241); a criação de Conselhos de Política de Administração e Remuneração de Pessoal (art. 39); a existência de escolas de governo (art. 39, $\S 2^{\circ}$ ); o desenvolvimento de programas de qualidade, produtividade, treinamento, desenvolvimento, modernização, reaparelhamento, e racionalização dos serviços públicos (art. 39, § $7^{\circ}$ ); avaliação especial de desempenho para a aquisição de estabilidade (art. $41, \S 4^{\circ}$ ); perda do cargo de servidor estável por reprovação em avaliação periódica de desempenho (art. $41, \S 1^{\circ}$, III) ${ }^{200}$,

Infelizmente, muitos dos mecanismos de controle e reação previstos pela Constituição ainda não foram regulamentados pelo legislador originário, colocando, em certa medida, a vontade constituinte sob jugo da própria ineficiência estatal (em não editar leis necessárias em tempo razoável). É, para nosso enguiço, um paradoxo.

\section{CAPÍTULO V - O PRINCÍPIO DA EFICIÊNCIA COMO PRINCÍPIO CONGLOBANTE}

A eficiência não se sobrepõe a qualquer outro princípio. Enquanto a legalidade é a base de onde de erige toda a ordem que orienta o Estado e seus prepostos, a eficiência é invólucro que une os princípios na busca da consecução dos fins postos pela própria Lei. De nada satisfaz a própria legalidade uma atuação incipiente, inócua, inútil. A legalidade não é fim em si mesma, mas parâmetro para o desenvolvimento de outras atividades. Nesse sentido, já alertava o professor que “(...) tal princípio não pode ser concebido (...) senão na intimidade do principio da legalidade, pois jamais uma suposta busca de eficiência justificaria postergação daquele que é o dever administrativo por excelência ${ }^{201}$ ". Isso posto, conclui-se que a busca da eficiência não arreda os demais princípios, ao contrário, auxilia-os à busca dos seus próprios objetivos e também ao objetivo geral, considerado como a incidência de todos eles sobre o objeto jurídico.

\footnotetext{
${ }^{200}$ ROCHA, Silvio Luís Ferreira da. Manual de Direito Administrativo. São Paulo: Malheiros Editores, 2013, pp. $81-82$.

${ }^{201}$ MELLO, Celso Antônio Bandeira de. Curso de Direito Administrativo. $31^{\text {a }}$ ed. São Paulo: Malheiros Editores, 2014, p. 125.
} 
Nesse sentido, concordamos com o ilustre doutrinador carioca:

"O Princípio da Eficiência de forma alguma visa a mitigar ou a ponderar o Princípio da Legalidade, mas sim a embeber a legalidade de uma nova lógica, determinando a insurgência de uma legalidade finalística e material - dos resultados práticos alcançados -, e não mais uma legalidade meramente formal e abstrata. É desta maneira que a aplicação tout court das regras legais deve ser temperada, não apenas pela outrora propugnada eqüidade, mas pela realização das finalidades constitucionais e legais aplicáveis à espécie. ${ }^{202,}$

\section{1 - EFICIÊNCIA, EFICÁCIA E EFETIVIDADE}

Embora os três termos sejam comumente empregados de forma indistinta, abrigam no seu núcleo conceitual diferenças de relevo para a análise do tema aqui proposto.

Podemos, sinteticamente, diferencia-los a tal medida: eficiência diz respeito à relação entre insumos e produtos. Um administrador mais eficiente é o que consegue produtos mais elevados em relação aos insumos necessários à sua concepção. É como uma fórmula matemática. Economicidade proporcional à produtividade; eficácia está relacionada ao alcance dos objetivos e resultados propostos. É a capacidade do administrador em conseguir resultados certos pela escolha adequada dos objetivos e meios para alcançá-los; efetividade é conseguir ser eficiente e eficaz ao mesmo tempo, isto é, obter o melhor resultado possível, maximizando os recursos disponíveis, e atingir os objetivos determinados. Carvalho Filho esclarece:

"A eficiência não se confunde com eficácia nem com efetividade. A eficiência transmite sentido relacionado ao modo pelo qual se processa o desempenho da atividade administrativa; a ideia diz respeito, portanto, à conduta dos agentes. Por outro lado, eficácia tem relação com os meios e instrumentos empregados pelos agentes no exercício de seus misteres na administração; o sentido aqui é tipicamente instrumental. Finalmente, a efetividade é voltada para os resultados obtidos com as ações administrativas; sobreleva nesse aspecto a positividade dos objetivos. O desejável é que tais qualificações caminhem simultaneamente, mas é possível admitir que haja condutas administrativas

\footnotetext{
${ }^{202}$ ARAGÃO, Alexandre Santos. O Princípio da Eficiência. Revista Eletrônica de Direito Administrativo Econômico, Salvador, Instituto de Direito Público da Bahia, $\mathrm{n}^{\circ}$ 4, nov/dez 2005, jan 2006. Disponível em <http://www.direitodoestado.com>. Acesso em: 26 de Outubro de 2014.
} 
produzidas com eficiência, embora não tenham eficácia ou efetividade. De outro prisma, pode a conduta não ser muito eficiente, mas, em face da eficácia dos meios, acabar por ser dotada de efetividade. Até mesmo é possível admitir que condutas eficientes e eficazes acabem por não alcançar os resultados desejados; em consequência, serão despidas de efetividade. ${ }^{203}$,"

Sendo complementares as anotações de Egon Bockmann:

"Merece atenção a diferença entre eficácia e eficiência. Eficácia administrativa diz respeito à potencialidade de concreção dos fins preestabelecidos em lei, [a situação atual de disponibilidade para produção de efeitos típicos, próprios do ato]. Já, a eficiência administrativa impõe que esse cumprimento da lei seja concretizado com um mínimo de ônus sociais, buscando o puro objetivo do atingimento do interesse público de forma ideal, sempre em benefício do cidadão. ${ }^{204,}$

O princípio da eficiência se concretiza quando, numa só realização da Administração verifica-se, in stricto sensu, os conceitos de eficiência, eficácia e efetividade.

\section{2 - O PRINCÍPIO DA EFICIÊNCIA COMO DIREITO FUNDAMENTAL}

Os Direitos fundamentais são fruto de um longo percurso histórico que modificou profundamente a relação de Poder entre o Estado e os indivíduos. Foram conquistados paulatinamente através de imposições políticas, sobreposições sociais e revoluções. Quanto ao último fenômeno, é paradigmática a Revolução Francesa, evento que repercute contemporaneamente na solução de conflitos sociais e na construção da Democracia. Acerca dela, anotou excelso jurisconsulto:

"O objetivo verdadeiro da Revolução é outro: construir o legislador virtuoso, necessariamente respeitoso com os direitos dos indivíduos e que fosse a expressão necessária da vontade geral. Porém, o legislador virtuoso não pode lesar os direitos individuais porque é necessariamente justo ao encarnar a vontade da nação e do povo. O problema não é limitar o arbítrio do legislador, a exemplo do modelo britânico, mas afirmar a autoridade do domínio da vontade geral sobre

\footnotetext{
${ }^{203}$ CARVALHO FILHO, José dos Santos. Manual de Direito Administrativo. 25 a edição. São Paulo: Atlas, 2012, p. 31.

${ }^{204}$ MOREIRA, Egon Bockmann. "Processo administrativo e princípio da eficiência". In: MUÑOZ, Guillermo Andrés, e SUNDFELD, Carlos Ari (coords.). As Leis de Processo Administrativo. Lei Federal 9.784/1999 e Lei Paulista 10.177/1988. $1^{a}$ ed., $2^{a}$ tir. São Paulo, Malheiros Editores, 2006, p. 123.
} 
o espírito da função. Assim, quanto mais forte o legislador, mais bem refletida será a vontade geral e mais seguras serão as liberdades e os direitos. ${ }^{205}$,

Com a constitucionalização dos Direitos Fundamentais, foram assuntas ao mais alto grau de importância jurídico-normativa as obrigações de abstenção estatal, assim como seu dever jurídico de agir sob determinadas circunstâncias. A referida constitucionalização também limitou a atuação legislativa ordinária a posteriori, petrificou as conquistas no corpo constitucional, de forma a dar-lhes característica de imutabilidade. O Professor Manoel Messias Peixinho esclarece:

"A partir de então, as constituições deixavam de ser meramente procedimentais e assumiam uma feição marcadamente substantiva, tomando desde logo decisões políticas importantes e restringindo o campo de atuação das instâncias legislativas ordinárias. ${ }^{206,}$

Ao nosso campo de estudo, especificamente, é relevante tratarmos dos chamados direitos fundamentais de segunda geração. Tais direitos compreendem os direitos da igualdade, que são os direitos sociais, econômicos e culturais, fruto da transição do Estado Liberal para o Estado Social. Eles representam, principalmente, uma reação ao quadro social que de desenhou durante o Estado liberal, em que alguns poucos concentravam a riqueza e a maioria vivia excluída de condições materiais mínimas. A verdade é que as promessas do Estado liberal, de liberdade, igualdade e fraternidade, só se mostraram acessíveis aos detentores de capital, excluindo a grande maioria da população e, isso, naturalmente, começou a gerar questionamentos, que desaguaram na transformação da fisionomia do Estado, que mais tarde passou a assumir uma feição social, intervencionista.

Esses direitos retratam um momento histórico no qual se reclamava a necessidade do Estado intervir no domínio econômico e distribuir riqueza por via da prestação de determinados serviços essenciais, como saúde,

\footnotetext{
${ }^{205}$ PEIXINHO, Manoel Messias. As contribuições da Revolução Francesa para a construção de uma Teoria Dos Direitos Fundamentais. 2010. 24 p. Disponível em: <http://www.publicadireito.com.br/artigos/?cod=39dd987a9d27f104>. Acesso em: 26 out. 2014.

${ }^{206}$ PEIXINHO, Manoel Messias. As teorias e os métodos de interpretação aplicados aos direitos fundamentais: doutrina e jurisprudência do STF e do STJ. Rio de Janeiro: Lumen Juris, 2010. p. 48 .
} 
educação, que não eram acessíveis a toda à população, mas somente àqueles que tinham condições econômicas. Leciona Carlos Weis:

"Diversamente dos direitos ditos de primeira geração, estes pressupõem o alargamento da competência estatal, requerendo a intervenção do Poder Público para reparar as condições materiais de existência de contingentes populacionais. Traduzem-se em direitos de participação que requerem uma política pública encaminhada a garantir o efetivo exercício daqueles e que se realizam através de serviços públicos. ${ }^{207 ", ~(G r i f o ~ n o s s o) . ~}$

A característica básica dos direitos fundamentais de segunda geração é o fato de serem direitos positivos, de natureza prestacional, no sentido de obrigarem o Estado a atuar positivamente, prestando políticas públicas de caráter social visando implementar um bem estar social.

Ora, como verificamos acima, tais direitos se concretizam por meio da atuação do Estado, na atividade administrativa, que incide sobre o domínio econômico dos particulares e no provimento de serviços públicos. Por via de dedução lógica, configura-se o princípio da eficiência como direito fundamental, pois, sem a observância desse princípio não há a realização dos fins sociais constitucionalmente previstos. Egon Bockmann Moreira vai ainda mais longe ao afirmar que:

"O princípio da efíciência dirige-se à maximização do respeito à dignidade da pessoa humana (CF., art. $\left.1^{\circ}\right)$. Esta é a finalidade básica da Administração Pública, num Estado Democrático de Direito. Não basta a inconsciente busca dos fins legais. Estes sempre devem ostentar qualidades humanas e sociais positivas. ${ }^{208,}$

Sob a perspectiva doutrinária apresentada, se faz pacífica a interpretação de que a observância, o respeito e a realização da atividade administrativa sob a égide do princípio da eficiência constitui um direito fundamental.

\footnotetext{
${ }^{207}$ WEIS, Carlos. Direitos humanos contemporâneos. $2^{\mathrm{a}}$ ed. São Paulo: Malheiros Editores, 2012, p. 49.

${ }^{208}$ MOREIRA, Egon Bockmann. "Processo administrativo e princípio da eficiência". In: MUÑOZ, Guillermo Andrés, e SUNDFELD, Carlos Ari (coords.). As Leis de Processo Administrativo. Lei Federal 9.784/1999 e Lei Paulista 10.177/1988. $1^{\mathrm{a}}$ ed., $2^{\mathrm{a}}$ tir. São Paulo, Malheiros Editores, 2006, p. 123.
} 


\section{3 - O CONTROLE JURISDICIONAL DO ATO ADMINISTRATIVO COM BASE NO PRINCÍPIO DA EFICIÊNCIA}

No Brasil há unidade de jurisdição. Nenhuma controvérsia pode ser excluída da apreciação do Poder Judiciário, conforme prevê o artigo $5^{\circ}$, XXXV da Constituição. O Poder Judiciário detém a universalidade da jurisdição, quer no que respeita ao juízo de legalidade, quer no que respeita ao juízo de constitucionalidade dos atos públicos e privados.

Não há necessidade de prévio esgotamento da via administrativa para propor a ação judicial. Alguma reserva ao controle judicial dos atos administrativos existia no passado, em relação aos atos de competência discricionária, que, contudo, foi, ao longo do tempo, eliminada, de modo que hoje se viabilizou o controle judicial dos atos administrativos discricionários. Nesse sentido, concordamos com o notório constitucionalista mato-grossense:

"Não apenas a perseguição e o cumprimento dos meios legais e aptos ao sucesso são apontados como necessários ao bom desempenho das funções administrativas mas também o resultado almejado. Com o advento do princípio da eficiência, é correto dizer que a Administração Pública deixou de se legitimar apenas pelos meios empregados e passou - após a Emenda Constitucional $\mathrm{n}$. $19 / 98$ - a legitimar-se também em razão do resultado obtido. ${ }^{209,}$

Arrebata, por seu turno, o grande administrativista:

“(...) a verificação da eficiência atinge os aspectos quantitativo e qualitativo do serviço, para aquilatar do seu rendimento efetivo, do seu custo operacional e de sua real utilidade para os administrados e para a Administração. Tal controle desenvolve-se, portanto, na tríplice linha administrativa, econômica e técnica. ${ }^{210 ", ~(G r i f o ~ n o s s o) . ~}$

Ora, havendo previsão constitucional que autoriza o controle jurisdicional dos atos administrativos e, preenchendo a doutrina o seu conteúdo e a lei especificando suas bordas, não há óbice à realização do

\footnotetext{
${ }^{209}$ MENDES, Gilmar Ferreira; BRANCO, Paulo Gustavo Gonet. Curso de Direito Constitucional. $6^{\mathrm{a}}$ ed. São Paulo: Saraiva, 2011, p. 866.

${ }^{210}$ MEIRELLES, Hely Lopes. Direito Administrativo brasileiro. $40^{\mathrm{a}}$ ed. atual. São Paulo: Malheiros Editores, 2014, pp. 113 - 114.
} 
referido controle, aliás, meio eficaz de se combater desmandos de governança pública e desrespeito ao erário. É também via para, calcado no princípio da eficiência, busquem os usuários do serviço público uma prestação adequada dos fins a que se propõe o Estado ${ }^{211}$. Carvalho Filho aborda a problemática:

"Atualmente, os publicistas têm apresentado vários estudos sobre a questão concernente ao controle da observância do princípio da eficiência. A complexidade que envolve o tema é compreensível: de um lado, há que se respeitar as diretrizes e prioridades dos administradores públicos, bem como os recursos financeiros disponíveis e, de outro, não se pode admitir que o princípio constitucional deixe de ser respeitado e aplicado. Os controles administrativo (de caráter interno e processado pelos próprios órgãos administrativos) e legislativo são reconhecidamente legítimos e indubitáveis à luz dos artigos 74 e 70 da Lei Maior, respectivamente. O controle judicial, entretanto, sofre limitações e só pode incidir quando se tratar de comprovada ilegalidade. Como tem consagrado corretamente a doutrina, 'o Poder Judiciário não pode compelir a tomada de decisão que entende ser de maior grau de eficiência ${ }^{212}$, nem invalidar atos administrativos invocando exclusivamente o princípio da eficiência. Note-se que a ideia não pretende excluir inteiramente o controle judicial, mas sim evitar que a atuação dos juízes venha a retratar devida intervenção no círculo de competência constitucional atribuída aos órgãos da Administração. ${ }^{213 ",}$

Nesse aspecto ousamos divergir do Professor fluminense, pois, não se trata de controle frente à estrita legalidade, mas, do controle com base na observância do Direito, da legalidade lato sensu, esta que agasalha não apenas a observância da lei (ou a reserva da lei para atuação do administrador), mas o cumprimento daquilo que prevê o ordenamento jurídico, o conteúdo não apenas das regras, mas também dos princípios. Nesse particular, perfilamo-nos com Aragão, que rompe com os aspectos meramente formais (estrita legalidade) para colocar o ato administrativo sob o lume do Direito em sua completude, assim colocando o seu controle sobre a forma e os fins. Brinda-nos com suas considerações:

"Não se trata de descumprir a lei, mas apenas de, no processo de sua aplicação, prestigiar os seus objetivos maiores em relação à observância pura e

\footnotetext{
${ }^{211}$ Para um detalhamento sobre o tema, recomendamos a consulta ao magnífico trabalho: ARAGÃO, Alexandre Santos de. Serviços Públicos e Direito do Consumidor: possibilidades e limites da aplicação do CDC. Revista de Direito da Procuradoria Geral do Estado do Rio de Janeiro, v. 60, 2012, pp. 27 - 49.

${ }^{212}$ FRANÇA, Vladimir da Rocha. Eficiência administrativa na Constituição Federal, RDA 220, 2000, p. 175.

${ }^{213}$ CARVALHO FILHO, José dos Santos. Manual de Direito Administrativo. 25a edição. São Paulo: Atlas, 2012, p. 31.
} 
simples de suas regras, cuja aplicação pode, em alguns casos concretos, se revelar antitética àqueles. Há uma espécie de hierarquia imprópria entre as meras regras contidas nas leis e os seus objetivos, de forma que a aplicação daquelas só se legitima enquanto constituir meio adequado à realização destes. ${ }^{214,}$

Ao passo que, como apontam Gilmar Mendes, Hely Lopes Meirelles e Alexandre Santos de Aragão, só há legitimação por parte da Administração Pública para a prática e manutenção do ato administrativo quando esta observa os fins legais e os atinge, sendo, portanto legítimo e legal o controle jurisdicional que busca impugnar ato que se demonstrar ineficiente (sob seu tríplice aspecto: ineficiente, ineficaz e inócuo).

\section{CONCLUSÃO - A FORÇA NORMATIVA DO PRINCÍPIO DA EFICIÊNCIA: A PREVALÊNCIA DOS ELEMENTOS FINALÍSTICOS SOBRE OS ELEMENTOS FORMAIS}

Chegamos ao derradeiro prélio do nosso trabalho monográfico, oportunidade em que buscaremos concatenar os temas abordados nos capítulos anteriores.

Anteriormente abordamos a força normativa da Constituição; a Teoria dos Princípios e a relevante abordagem realizada quanto a esta por Humberto Ávila; a normatividade dos princípios, sobretudo dos princípios imbuídos de caráter constitucional; abordamos a origem do Poder do Estado e as suas formas de manifestação; a unicidade e invisibilidade do referido Poder; a capacidade do Estado auto-organizar-se; os fins do Estado moderno; realizamos longa análise da Administração Pública brasileira e suas mais recentes tendências; seguindo a sistematização constitucional, fizemos uma leitura dos institutos da Administração previstos na Carta de 1988; examinamos a Emenda Constitucional ${ }^{\circ} 19$ e seus reflexos no texto constitucional; buscamos a natureza jurídica dos princípios implícitos e explícitos do Direito Administrativo brasileiro; aprofundamo-nos no Princípio da Eficiência e como este é definido pela doutrina publicista;

\footnotetext{
${ }^{214}$ ARAGÃO, Alexandre Santos. O Princípio da Eficiência. Revista Eletrônica de Direito Administrativo Econômico, Salvador, Instituto de Direito Público da Bahia, $\mathrm{n}^{\circ}$ 4, nov/dez 2005, jan 2006. Disponível em <http://www.direitodoestado.com>. Acesso em: 26 de Outubro de 2014.
} 
ensaiamos a relação do Princípio da Eficiência e a base principiológica constitucional; distinguimos eficiência, eficácia e efetividade; empreendemos a qualificação do Princípio da Eficiência como direito fundamental; defendemos o controle jurisdicional do ato administrativo com base no princípio da eficiência; e agora realizamos a ilação monográfica abordando a "prevalência dos elementos finalísticos sobre os elementos formais".

Quanto ao tema, fez sucinta e cirúrgica definição Maria Sylvia Zanella Di Pietro:

"O principio da eficiência apresenta, na realidade, dois aspectos: pode ser considerado em relação ao modo de atuação do agente público, do qual se espera o melhor desempenho possível de suas atribuições, para lograr os melhores resultados; e em relação ao modo de organizar, estruturar, disciplinar a Administração Pública, também com o mesmo objetivo de alcançar os melhores resultados na prestação do serviço público. ${ }^{215}$,

Em ambos os aspectos, destaca Di Pietro, há uma clara finalidade. E é a normatividade do princípio da eficiência na Administração Pública para a persecução dos seus fins que propomos na presente monografia. Mitigando a análise formal, para imprimir uma avaliação de legalidade e legitimidade que se dê sobre o atendimento dos fins da norma. É nesse sentido que se manifestam Ferraz e Dallari:

\begin{abstract}
"Isso significa que é preciso superar concepções puramente burocráticas ou formalísticas, dando-se maior ênfase ao exame da legitimidade, da economicidade e da razoabilidade, em benefício da eficiência. Não basta ao administrador demonstrar que agiu bem, em estrita conformidade com a lei; sem se divorciar da legalidade (que não se confunde com a estrita legalidade), cabe a ele evidenciar que caminhou no sentido da obtenção dos melhores resultados. Daí dizemos que, com a concepção do princípio da eficiência, abrigou-se o administrador brasileiro não só ao comando da 'boa administração', mas ao império da 'melhor administração', inclusive com a possibilidade de verificação jurisdicional da realização desta última, levando até mesmo à desconstituição de uma opção que seja simplesmente 'boa' ${ }^{216 ” . ~(G r i f o ~ n o s s o) . ~}$
\end{abstract}

Os jurisconsultos supracitados não apenas agasalham o deslocamento da verificação para a finalidade em divórcio com a leitura exclusiva da

\footnotetext{
${ }^{215}$ DI PIETRO, Maria Sylvia Zanella. Direito Administrativo. 27 ed. São Paulo: Atlas, 2014, p. 84.

${ }^{216}$ FERRAZ, Sérgio e DALLARI, Adilson Abreu. Processo administrativo. $3^{\text {a }}$ ed. São Paulo: Malheiros Editores, 2001, pp. 122 - 123.
} 
atenção às formalidades, como corroboram a ideia defendida no item 5.3 de que a não atenção ao princípio da eficiência dá ensejo à desconstituição do ato administrativo. Destacam ainda, a prevalência do conceito de melhor administração, sendo incapaz de atingir os fins do princípio em tela a atuação estatal que se escore exclusivamente na observância da legalidade, transportando para o mundo factual a observância da norma de forma infrutífera. Cumprir a lei já não basta, é necessário revestir seu cumprimento de eficiência. De mesmo rumo são as lições:

"Não se considera mais suficiente que os governantes não violem a lei: exigi-se deles a redução do desemprego, o crescimento econômico, o combate à pobreza, solução para os problemas de habitação e saúde. A discussão sempre se coloca em relação a quais são as políticas mais adequadas para atingir estes fins, mas não há dúvidas de que a lei deixou de ser apenas um meio para impedir a arbitrariedade, para se converter em ponto de partida para uma série de atividades nas quais há uma margem de delegação e de discricionariedade e um crescente espaço para a técnica. O dilema deve, a nosso ver, ser resolvido não pelo menosprezo da lei, mas pela valorização de seus elementos finalísticos. É sob este prisma que todas as suas regras devem ser interpretadas e aplicadas, ou seja, todo ato, normativo ou concreto, só será válido ou validarmente aplicado se for a maneira mais eficiente ou, na impossibilidade de se definir esta, se for pelo menos uma maneira razoavelmente eficiente de realização dos seus objetivos. ${ }^{217}$," (Grifo nosso).

Observa-se, por consequência, que está superada a legalidade pela mera adstrição do Poder Estatal. Não se busca mais pela via normativa tão somente a limitação do exercício do Poder, mas mais do que isso, imputalhe atividade que deve ser desempenha de certo modo para o alcance de determinado fim, tendo este último a sua concepção ideal. Conclui nesse sentido Morand:

"As normas jurídicas passam a ter o seu critério de validade aferido não apenas em virtude da higidez do seu procedimento criador, como da sua aptidão para atender aos objetivos da política pública, além da sua capacidade de resolver os males que esta pretende combater. ${ }^{218,}$

\footnotetext{
${ }^{217}$ ARAGÃO, Alexandre Santos de. "Ensaio de uma visão autopoiética do direito administrativo". RDPE 4. Belo Horizonte, Fórum, outubro-dezembro/2003, p. 11 - 12. apud FERRAZ, Sérgio e DALLARI, Adilson Abreu. Processo administrativo. $3^{\mathrm{a}}$ ed. São Paulo: Malheiros Editores, 2001, p. 125.

${ }^{218}$ MORAND, Charles-Albert. Le Droit Néo-Moderne des Politiques Publiques, LGDJ, Paris, 1999, p. 95. apud ARAGÃO, Alexandre Santos. O Princípio da Eficiência. Revista Eletrônica de Direito Administrativo Econômico, Salvador, Instituto de Direito Público da Bahia, nº 4, nov/dez
} 
O Direito Administrativo, sempre relacionado às formalidades e reservando ao Estado uma atuação prioritariamente autônoma toma, por via da normatividade do princípio da eficiência, tônica de cunho material, incidindo também na relação de comando e resultado, atribuições que the impõe a norma. Ensina-nos sobre a mutação conceitual as anotações:

"Estamos diante de uma importante mudança na estrutura das normas jurídicas. O modelo das normas jurídicas 'hipótese de incidência $\rightarrow$ sanção' continua a existir, mas não é mais o único nem o mais importante, a ele tendo se somado o das normas jurídicas estruturadas pelo esquema 'finalidades $\rightarrow$ meios de alcance destas finalidades ${ }^{, 219, "}$.

Depois de um longo processo histórico onde se buscou num primeiro momento delimitar o exercício do Poder, passamos à fase de atribuição de tarefas ou fins, tendo sido nessa segunda fase exercido um controle que se limitava ao aspecto formal, de cumprimento por hermenêutica literal da norma para, por via da normatividade dos princípios, em especial o princípio da eficiência, buscarmos o controle sobre a atuação da Administração Pública verificando se esta age na busca (e atinge) os objetivos que a Lei imputa-lhe. Iannotta descreve a mudança de paradigma:

"A interpretação da norma é obviamente finalizada à aplicação a uma realidade delimitada e circunscrita. Quem decide, sobretudo na fase de emissão da decisão, deve colher na norma, prioritariamente, os objetivos das leis, os fins, a vontade do legislador. Os bens que a norma quis proteger e, portanto, o resultado que quis alcançar; devendo-se distinguir, portanto, no interior da norma, aquilo que é verdadeiramente finalístico (bens a serem protegidos, males a serem evitados) dos outros componentes (meios, instrumentos, formas) correspondentes aos vários planos da realidade reproduzida e sintetizada pela norma. ${ }^{220,}$

Como colocado na introdução, redigimos tais considerações num momento de efervescência social, onde o detentor do Poder, ou seja, o Povo, se indigna e vai às ruas bradar a sua insatisfação com o Estado

2005, jan 2006. Disponível em <http://www.direitodoestado.com>. Acesso em: 26 de Outubro de 2014.

${ }^{219}$ ARAGÃO, Alexandre Santos. O Princípio da Eficiência. Revista Eletrônica de Direito Administrativo Econômico, Salvador, Instituto de Direito Público da Bahia, no 4, nov/dez 2005, jan 2006. Disponível em <http://www.direitodoestado.com>. Acesso em: 26 de Outubro de 2014.

${ }^{220}$ IANNOTTA, Lucio. Princípio di Legalità e Amministrazione di Risultato, in Amministrazione e Legalità - Fonti Normativi e Ordinamenti (Atti del Convegno, Macerata, 21 e 22 maggio 1999), Giuffrè Editore, Milano, 2000, pp. 44 - 45. apud ARAGÃO, Alexandre Santos. O Princípio da Eficiência. Revista Eletrônica de Direito Administrativo Econômico, Salvador, Instituto de Direito Público da Bahia, $\mathrm{n}^{\mathrm{o}}$ 4, nov/dez 2005, jan 2006. Disponível em <http://www.direitodoestado.com>. Acesso em: 26 de Outubro de 2014. 
incompetente, que não consegue prover de forma que atinja os fins previstos pela Lei, sobretudo, na oferta adequada de serviços públicos. É grave a situação de descumprimento do princípio da eficiência também nessa espécie de atuação administrativa. Adentrando ao tema, Carvalho Filho bem colocou:

"Com a inclusão (do princípio da eficiência no caput do artigo 37 da Constituição), pretendeu o Governo conferir direito aos usuários dos diversos serviços prestados pela Administração ou por seus delegados e estabelecer obrigações efetivas aos prestadores. Não é difícil perceber que a inserção desse princípio revela o descontentamento da sociedade diante da sua antiga impotência para lutar contra a deficiente prestação de tantos serviços públicos, que incontáveis prejuízos já causou aos usuários. De fato, sendo tais serviços prestados pelo Estado ou por delegados seus, sempre ficaram inacessíveis para os usuários os meios efetivos para assegurar seus direitos. Os poucos meios existentes se revelaram insuficientes ou inócuos para sanar as irregularidades

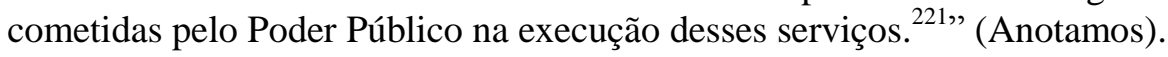

Forma de reação aos desmandos do Estado na prestação de serviços públicos destacamos e defendemos no item 5.3, supra.

A defensa da normatividade do princípio da eficiência deve ser alargada na doutrina para que esta sirva de subsídio a decisões judiciais que obriguem a Administração (ou seus prepostos) ao cumprimento da teleologia legal. O Direito não pode mais compactuar com um Estado inábil no desempenho daquilo que a Lei lhe atribuiu. Socorro apenas na política não se mostra suficiente, pois, sendo incompetente o agente político a mazela é do Povo, o próprio detentor do Poder.

Escorados na discricionariedade administrativa é que ficaremos inertes diante do derrame que se dá ao erário, às posturas teratológicas dos gestores, à criação das 'dificuldades' para que haja soluções lesivas ao patrimônio público? Trata-se de escárnio aos populares nos depararmos diuturnamente com as manchetes que lançam luz sobre as contratações em regime de emergência, sendo que a "emergência" foi tão somente a desídia da Administração.

\footnotetext{
${ }^{221}$ CARVALHO FILHO, José dos Santos. Manual de Direito Administrativo. $25^{\mathrm{a}}$ edição. São Paulo: Atlas, 2012, p. 29.
} 
Enquanto não criarmos a cultura de normatividade do princípio da eficiência sobre toda e qualquer atuação do Estado continuaremos a deixar os cidadãos entregues ao sabor da sorte, pois, talvez estes tenham a graça de viverem num ente estatal que cumpra mediocremente as suas atribuições constitucionais.

Analisou a influência do Direito em outras áreas do mundo factual e a efetividade das normas Norberto Bobbio:

"(É urgente uma) Teoria Realista do Direito, que volta a sua atenção mais à efetividade que à validade formal das normas jurídicas, colocando o acento, mais do que sobre a auto-suficiência do sistema jurídico, sobre a interrelação entre sistema jurídico e sistema econômico, entre sistema jurídico e sistema político, entre sistema jurídico e sistema social em seu conjunto, (...) procurando o seu objeto, em última instância, não tanto nas regras do sistema dado, mas sim na análise das relações e dos valores sociais dos quais se extraem as regras dos sistemas. (...) A ciência jurídica não é mais uma ilha, mas uma região

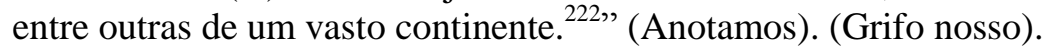

Para nós é relevante a observação final de Bobbio, pois, o Direito tem que se voltar para a realidade, não se divorciando da forma, inimiga máxima do arbítrio, mas indo ao encontro da eficiência (conceito que abriga a eficiência stricto sensu, a eficácia e a efetividade).

Da revolta que resite no íntimo de cada cidadão consciente de seus direitos e deveres; da boa-fé de cada operador do Direito; da indignação de cada mandatário do Estado; da busca de um país mais justo para si e os seus; é que será construída a efetivada uma cultura que imbuirá àquele que dirige a Administração de responsabilidade, os populares de legitimidade para exigir a "melhor administração" e o Poder Judiciário de força para impor à Administração Pública, com base na normatividade desse magnífico princípio moderno, as correições necessárias para o respeito à

\footnotetext{
${ }^{222}$ BOBBIO, Norberto. Dalla Strutura alla Funzione: nuovi studi di teoria del diritto, Edizioni di Comunità, Milano, 1977, p. 56. apud ARAGÃO, Alexandre Santos. O Princípio da Eficiência. Revista Eletrônica de Direito Administrativo Econômico, Salvador, Instituto de Direito Público da Bahia, $n^{\circ}$ 4, nov/dez 2005, jan 2006. Disponível em <http://www.direitodoestado.com>. Acesso em: 26 de Outubro de 2014.
} 
vontade da Lei, ou seja, obediência máxima aos direitos e à vontade do Povo.

“O Povo, por ele próprio, quer sempre o bem, mas, por ele próprio, nem sempre o conhece."

Jean-Jacques Rousseau ${ }^{223}$

${ }^{223}$ ROUSSEAU, Jean-jacques. Do Contrato Social. São Paulo: Martins Fontes, 1989. Disponível em: <http://www.ebooksbrasil.org/adobeebook/contratosocial.pdf〉. Acesso em: 26 out. 2014, p. 40 . 


\section{REFERÊNCIAS BIBLIOGRÁFICAS}

ALEXY, Robert. Teoria dos direitos fundamentais. Trad. Virgílio A. Da Silva. São Paulo: Malheiros Editores, 2008.

ARAGÃO, Alexandre Santos de. "Ensaio de uma visão autopoiética do direito administrativo". RDPE 4. Belo Horizonte, Fórum, outubro-dezembro/2003.

O Princípio da eficiência. Revista Eletrônica de Direito Administrativo Econômico, Salvador, Instituto de Direito Público da Bahia, nº 4, nov/dez 2005, jan 2006. Disponível em <http://www.direitodoestado.com>. Acesso em: 26 de Outubro de 2014.

ÁVILA, Humberto. Teoria dos princípios - da definição à aplicação dos princípios jurídicos. 15ª ed., revista e ampliada. São Paulo: Malheiros Editores, 2014.

BARROSO, Luís Roberto. Curso de direito constitucional contemporâneo: os conceitos fundamentais e a construção do novo modelo. $3^{\text {a }}$ ed. São Paulo: Saraiva, 2011.

BOBBIO, Norberto. Dalla Strutura alla Funzione: nuovi studi di teoria del diritto, Edizioni di Comunità, Milano, 1977.

BONAVIDES, Paulo. Ciência Política, 18ª ed. São Paulo: Malheiros Editores, 2011.

Curso de direito constitucional. 29a ed. São Paulo: Malheiros Editores, 2014.

Reflexões - Política e Direito. $3^{\text {a }}$ ed. São Paulo: Malheiros Editores, 1998.

Teoria do Estado, 8 a ed., São Paulo: Malheiros Editores, 2010.

BRASIL. Constituição (1988). Constituição da República Federativa do Brasil. Brasília, DF: Senado, 1988.

Lei n. ${ }^{\circ}$ 9.784, de 29 de Janeiro de 1999. Regula o processo administrativo no âmbito da Administração Pública Federal. Diário Oficial [da] República Federativa do Brasil, Brasília, DF, 11 mar. 1999.

CARVALHO FILHO, José dos Santos. Manual de direito administrativo. $25^{\mathrm{a}}$ ed. Rio de Janeiro: Atlas: 2012. 
DANTAS, Eduardo Sousa. A força normativa da constituição e a eficácia das normas constitucionais no direito brasileiro. Revista Direito e Liberdade - ESMARN - v. 11, n. 2, p. $21-36-$ jul/dez 2009.

DI PIETRO, Maria Sylvia Zanella. Direito Administrativo. 27 ed. São Paulo: Atlas, 2014.

DWORKIN, Ronald. Uma questão de princípio. São Paulo: Martins Fontes, 2000.

FALCÃO, Raimundo Bezerra. Hermenêutica. $2^{a}$ ed. São Paulo: Malheiros Editores, 2010 .

FERRAZ, Sérgio e DALlARI, Adilson Abreu. Processo Administrativo. $3^{\text {a }}$ ed. São Paulo: Malheiros Editores, 2001.

FRANÇA, Vladimir da Rocha. Eficiência administrativa na Constituição Federal, RDA 220, 2000.

GRAU, Eros Roberto. O perigoso artifício da ponderação entre princípios - Sobre a prestação jurisdicional - Direito Penal. São Paulo: Malheiros Editores, 2010.

HESSE, Konrad. A força normativa da Constituição. Trad. Gilmar Ferreira Mendes. Porto Alegre: Sérgio Fabris Editor, 1991. [orig. Die normative Kraft der Verfassung, J.C.B. Mohr (Paul Siebeck), Tübingen].

IANNOTTA, Lucio. Princípio di Legalità e Amministrazione di Risultato, in Amministrazione e Legalità - Fonti Normativi e Ordinamenti (Atti del Convegno, Macerata, 21 e 22 maggio 1999), Giuffrè Editore, Milano, 2000.

JELLINEK, Georg. Allgemeine Staatslehre. Nabu Press: 2010.

KAGAN, Shelly. The Limits of Morality, Oxford, Clarendon, 1989.

MACHADO, COSTA. Constituição Federal Interpretada, artigo por artigo, parágrafo por parágrafo. $4^{\mathrm{a}}$ ed. Barueri: Manole, 2013.

MEIRELLES, Hely Lopes. Direito Administrativo brasileiro. $40^{\mathrm{a}}$ ed. atual. São Paulo: Malheiros Editores, 2014.

MELlO, Celso Antônio Bandeira de. Curso de Direito Administrativo. 31 a ed. São Paulo: Malheiros Editores, 2014. 
MENDES, Gilmar Ferreira; BRANCO, Paulo Gustavo Gonet. Curso de Direito Constitucional. $6^{a}$ ed. São Paulo: Saraiva, 2011.

MORAND, Charles-Albert. Le Droit Néo-Moderne des Politiques Publiques, LGDJ, Paris, 1999.

MOREIRA, Egon Bockmann. "Processo administrativo e princípio da eficiência". In: MUÑOZ, Guillermo Andrés, e SUNDFELD, Carlos Ari (coords.). As Leis de Processo Administrativo. Lei Federal 9.784/1999 e Lei Paulista 10.177/1988. $1^{\text {a }}$ ed., $2^{\text {a }}$ tir. São Paulo, Malheiros Editores, 2006.

NOZICK, Robert. Anarchy, Stae and Utopia, Oxford, Blackwell, 1975.

PEIXINHO, Manoel Messias. As contribuições da Revolução Francesa para a construção de uma Teoria Dos Direitos Fundamentais. 2010. 24 p. Disponível em: <http://www.publicadireito.com.br/artigos/?cod=39dd987a9d27f104>. Acesso em: 26 out. 2014.

As teorias e os métodos de interpretação aplicados aos direitos fundamentais: doutrina e jurisprudência do STF e do STJ. Rio de Janeiro: Lumen Juris, 2010.

PERO, V.; MIHESSEN, V. Mobilidade Urbana e Pobreza no Rio de Janeiro. Rio de Janeiro: BNDES/ANPEC, 2012 (Séries Working Paper BNDES/ANPEC nº 46).

REALE, Miguel. Lições Preliminares de Direito. 27ª ed. São Paulo: Saraiva, 2014. Teoria do Direito e do Estado. $5^{a}$ ed. São Paulo: Saraiva, 2010.

RIGOLIN, Ivan Barbosa. O servidor público nas reformas constitucionais. Rio de Janeiro: Fórum: 2003.

ROCHA, Silvio Luís Ferreira da. Manual de Direito Administrativo. São Paulo: Malheiros Editores, 2013.

ROUSSEAU, Jean-jacques. Do contrato social. São Paulo: Martins Fontes, 1989. Disponível em: <http://www.ebooksbrasil.org/adobeebook/contratosocial.pdf〉. Acesso em: 26 out. 2014.

SILVA NETO, Manoel Jorge. Curso de Direito Constitucional. $5^{\text {a }}$ ed., Rio de Janeiro: Lumen Juris, 2009. 
SILVA, José Afonso da. Aplicabilidade das normas constitucionais. $7^{\mathrm{a}}$ ed. São Paulo: Malheiros Editores, 2007.

Curso de Direito Constitucional positivo. $34^{\mathrm{a}}$ ed. São Paulo: Malheiros Editores, 2010.

Manual da Constituição de 1988. São Paulo: Malheiros Editores, 2002.

TANAKA, Sônia Yuriko Kanashiro. Direito Administrativo. São Paulo: Malheiros Editores, 2008.

TASSINOPOULOS, MICHEL. Traité des Actes Administratifs, Athenas, Librairie Sirey, 1954.

VASCONCELOS, Arnaldo. Teoria da Norma Jurídica. $6^{\text {a }}$ ed. São Paulo: Malheiros Editores, 2006.

WEIS, Carlos. Direitos Humanos contemporâneos. $2^{\mathrm{a}}$ ed. São Paulo: Malheiros Editores, 2012. 